\title{
Mutations: What Are They?
}

\author{
V. A. Kordium
}

The Institute of Molecular Biology and Genetics

150 Zabolotny Str., Kyiv 03143, Ukraine

kordium@ukr.net

\begin{abstract}
The conceptions of mutations are analyzed. The literature data that are not consistent with the existent ideas about mutations are presented. The statement about physiological ambiguity of mutations and their biological role is formulated, according to which the mutations in soma perform a regulatory role, therefore, they are a normal component of biological processes, controlled by an organism. Once uncontrolled, mutations in soma lead to oncogenesis. As for a germ route, mutations provide the elimination of their carriers through cascade integral processes, thus realizing the function of purification. Being out of control and not resulting in elimination of their carriers, the mutations are realized into the whole range of hereditary pathologies - from a latency form ("mutational load") to a bright manifestation.
\end{abstract}

Key words: mutations, regulation, soma, germ route

The term 'mutation' was introduced by Hugo De Vries in 1901. Nowadays this term belongs to the list of those, which are commonly known to everyone. General and fundamental concept of what the mutations are is pretty close to the classical and commonly accepted view, i.e. mutations are suddenly occurring stable changes in genetic apparatus, which include both the transition of genes from one allele state into the other, and various changes in number and structure of chromosomes [1], and classical hereditary diseases are attached as obvious and absolutely comprehensible evidence to the given definition (Table 1).

All the rest are the issues of specification, correction, and classification, like "recessive allele influences phenotype, in case the genotype is homozygous". Otherwise, it seems like it does not, and so forth and so on...

(C) V. A. KORDIUM, 2007
Such a simple logical causal-consequential connection, i.e. disorders in genome $>$ changes in phenotype, together with countless experimental evidences, their reproducibility, and, in some cases, traceability of all stages, all links of the chain - from quantum levels to external manifestation of the object (phenotype), brought us to the situation, where not only doubts but even the signs of lack of understanding were apprehended with sincere amazement, as the manifestations of natural dullness, laziness, preventing from consulting the text-books etc. Regardless of the fact that reliable, not fitting into generally accepted concept, experimental material was accumulated from the very beginning of the process of studying mutations, only gradually this material became sufficient for new comprehension of this problem. Let us perform a sort of analysis, shall we.

Let us begin with phenomenology. Penetrance and expressiveness are considered to be "antiquity leg- 
Table 1

Examples of diseases, associated with the replacements of nucleotides in encoding regions of genes [2]

\begin{tabular}{|c|c|c|c|c|}
\hline Gene & $\begin{array}{l}\text { Nucleotide } \\
\text { replacement }\end{array}$ & $\begin{array}{l}\text { Amino acid } \\
\text { replacement }\end{array}$ & Defect & Reference \\
\hline Adenosine aminase & $\mathrm{G}$ for $\mathrm{A}$ & Arg-Gln & Inactive & Bonthron, 1985 \\
\hline Antithrombin III & & Pro-Leu & Inactive & Bock, 1985 \\
\hline Insulin & $\mathrm{T}$ for $\mathrm{C}$ & Phe-Ser & Receptor binding site (dominant) & Haneda, 1983 \\
\hline Insulin receptor & $\mathrm{G}$ for $\mathrm{T}$ & Arg-Ser & Processing of receptor predecessor & Yoshimasa, 1988 \\
\hline Factor VIII & $\mathrm{C}$ for $\mathrm{T}$ & Pro-Arg & Inactive & Levinson, 1987 \\
\hline Factor IX & & Arg-Gln & Pre-peptide processing & Bentley, 1986 \\
\hline Triosephosphate isomerase & $\mathrm{G}$ for $\mathrm{C}$ & Glu-Asp & Labial in all tissues & Daar, 1986 \\
\hline Uroporphyrinogen decarboxylase & $\mathrm{G}$ for $\mathrm{A}$ & Gly-Glu & Labial in all tissues & de Verneuili, 1986 \\
\hline Aldolase B & $\mathrm{G}$ for $\mathrm{C}$ & Ala-Pro & Substrate binding & Cross, 1988 \\
\hline a2(I) Collagen & $\mathrm{C}$ for $\mathrm{G}$ & Gly-Arg & Helix formation (dominant) & Wenstrup, 1988 \\
\hline HPRT & $\mathrm{G}$ for $\mathrm{A}$ & Phe-Leu & Stable & Davidson, 1988 \\
\hline
\end{tabular}

ends". This is the case when the feature is either present or absent, or manifested more or manifested less. Though the changes in genome are present in all of such cases. Suppressor mutations belong to the same category. Changes in genome have a corresponding feature, but when one more mutation occurs in another gene, even though the first mutation did not disappear, phenotype returned to its normal condition. Again completely or incompletely. Or it is due to the 'position effect', when the feature depends on the location of one and the same gene in some genome regions. And definitely we can not talk about "either yes or no" at recessiveness.

Of course, the principal mechanisms of such indirect non-linear correlation "gene $>$ feature" (or in a more generalized form "genotype $>$ phenotype") at the time of their introduction were put into scientific practise as notions, and later on studied in details, included into text-books, and acquired common acceptance. And this common acceptance put 'what really matters' in mutagenesis on the background, i.e. the fact that the changes in an individual gene, as well as big genomic ones (the sets of all information), even identical, on the one hand ("in some cases"), may not only lead to, but actually and ubiquitously result in identical changes, and, on the other hand ("in other cases"), they may result in identical phenotype changes so rigorously, and may as well become the reason of other changes, not identical ones at all. With all the obviousness of why it happens so, all these whys serve to the concretisation of the notion - local, identical, close, similar changes in genotype may influence phenotype differently or do not have any influence at all. Meanwhile, when this notion is pattered, than all this, is completely and choicelessly added up to accidents, possibilities, indefinitenesses. After all, they are mutations, are they not?

Gradually, the data requiring new assumptions began accumulating. As it turned out, average (i.e. vitally optimal) mutation rates in different organisms differ more than 6000 (!) times, and the boundary mutation rates are more than 10 (!!) times different [3]. It is impossible to explain such difference with whatever assumption involved. Thereafter, a very important funda- 
Table 2

Frequency of chromosomal anomalies in human oocytes [5]

\begin{tabular}{|c|c|c|c|c|c|c|c|}
\hline \multirow[b]{2}{*}{$\begin{array}{c}\text { Number of } \\
\text { oocytes }\end{array}$} & \multirow{2}{*}{$\begin{array}{c}\text { Normal } \\
\text { chromosomal } \\
\text { complex }\end{array}$} & \multicolumn{4}{|c|}{ Abnormal chromosomal complex } & \multirow{2}{*}{$\begin{array}{l}\text { Total \% of } \\
\text { anomalies }\end{array}$} & \multirow[b]{2}{*}{ Reference } \\
\hline & & Hypoploidy & Hyperploidy & Diploidy & $\begin{array}{c}\text { Structural } \\
\text { abnormalities }\end{array}$ & & \\
\hline 44 & 42 & - & 2 & - & 1 & 4,5 & [8] \\
\hline 50 & 34 & 14 & 1 & - & 1 & 32 & [9] \\
\hline 17 & 9 & 6 & 2 & - & - & 47 & {$[10]$} \\
\hline 251 & 192 & 33 & 20 & 5 & 1 & 23,5 & {$[11]$} \\
\hline 188 & 153 & 10 & 16 & - & - & 18,6 & [12] \\
\hline 316 & 234 & \multicolumn{2}{|c|}{76} & 6 & - & 28 & [13] \\
\hline 139 & 124 & 12 & 3 & - & - & 8 & [6] \\
\hline 65 & 31 & 10 & 7 & 14 & - & 47,7 & [7] \\
\hline $100 \%$ & $76.8 \%$ & $13.3 \%$ & $7.3 \%$ & $2.3 \%$ & $0.3 \%$ & $23.2 \%$ & - \\
\hline
\end{tabular}

mental conclusion has been made, which is well-proven at all of the stages of the process - the mutation rate is determined not by spontaneous mutagenesis as a result of external influence with all of its chances, but by intracellular processes. However, this conclusion was followed by a strict limitation by efficiency, perfection, etc of reparation. And then, finally, it was reduced to the chance. Let it not be pure but via reparation efficiency (evolutionally conditioned, as a result of mutations, spontaneous ones, of course, of these or those genes of reparation system, etc).

The following load of experimental data, which did not fit the concept, even taking into account all of its modifications, was dealing with not only material accumulation, but to a greater extent, with the appearance of new methods of investigation. The use of transgenic mice with special experimental genes for the sake of investigation of mutagenesis allowed making the following general conclusions: i) mutation rate within the individual is tissue-specific; ii) such specificity is not correlated with proliferation rate; iii) each type of tissue is specific for its type of mutations [4]. And it is not mice only, the general percentage of human chromosomal abnormalities (microscope-visible!) in oocytes, according to the data of different authors, varies from 4.5 to 47.7\% [5]. Moreover, the data are not presented in mean values, and not in comparison of sick vs. healthy (Table 2).

And in different genes in various cells (normally), and not in living in general, but in human being the fluc-

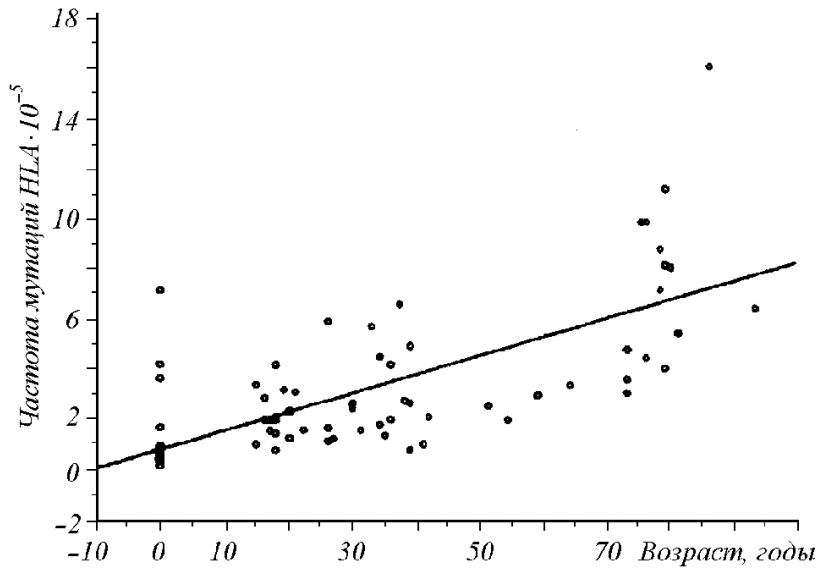

Fig.1 Frequency of mutations in gene locus of the main histocompatibility complex in normal human lymphocytes of different age $(r=0.69 ; \mathrm{p}<0.0001)[6]$

tuations of the level of mutations reach $10^{4}$. Direct detection of mutations in human cells, according to several authors' data, are as follows:

$\begin{array}{ll}\text { Globin (erythrocytes) } & 10^{-8} \\ \text { Lymphocytes HLA-A3 } & (2-8) \cdot 10^{-5} \\ \text { Lymphocytes HLA-A2 } & (2-8) \cdot 10^{-6} \\ \text { Kidney tubular epithelium (HPRT) } & 2 \cdot 10^{-5}-2.5 \cdot 10^{-4}\end{array}$

For different individuals, the differences in mutation rates of one and the same gene are not just multiple, but those of the 95-year-old may not exceed those of the 
new-born one (Fig.1). At the same time humans, mice, and other living creatures still live, and live not badly at all. The connection between phenotype and genotype is rather vague. The fact of its existence is naked-eye visible, yet it is rather crooked one, isn't it? In these kinds of cases, the processes, which determine everything at the molecular level and are subsequently realized into the phenotype, after exhaustive examination, will put all transformations and chains of events into their places, and the picture will be absolutely clear, whereas today's uncertainties will be cast out into the History textbooks. Let's see what is already known at the molecular level, shall we? Classical genetics is the way from phenotype to genotype and molecular genetics (in its variants of determination of genes functions), studying this way experimentally - by means of introduction or "redirection" of genes, i.e. from genotype to phenotype, acquired a specific (commonly acknowledged) name of Inverse Genetics. The latter has also provided the material of principal importance. The assessment of the accumulated material (accepting it generally and not separately) results in pronounced intellectual stress in the attempts of coordinating the obtained with classical theory.

Generally, the mutations proper, as fundamental principle of all further events is some sort of change in the sequence of grounds of one DNA chain, which, for some reason (which is always reduced to chance), did not restore to its previous state, but resulted in the formation of complementary base in the second chain, which corresponds to the change occurred. As a result, such change is present already in both chains. The variants for such event are numerous, but they are always followed by some sort of "securing of changes". While the change (any change) is present in one DNA chain it is not a mutation yet. It activates the corresponding reparation system. In case when the change is repaired according to the complementarity of the second chain, then everything will resume to its normal course. No mutation acquired. But if the base of the second chain "corrected" itself to the complementary changed second chain, the mutation is realized. And from now on, it is no longer the mutation but something of the organism's proper, its own, which has to be protected, secured (change-appropriately), repaired in the case of damage (even if the damage is directed towards the res- toration of the initial state), and so forth and so on. The change has been secured, transferring from the category of disorders into the category of mutations, as on molecular, genetic, informational level, the secured change does not differ essentially from the rest of base sequence. Even terminologically, the return to the norm is called the reverse mutation. It is the realization of the information on all subsequent stages of the process from the DNA sequence to the distinctive feature that determines "what is what". The ambiguity of the issue of mutation starts at this point - as "what is what" is some sort of absolute. And this "what is what" is completely dependent on where, at what moment, and in what combination the realization takes place. All alternative processes in the cell, i.e. alternative transcription, polyadenilation, splicing, etc can evidence to that. One and the same DNA sequence, depending on its realization, may be phenotypically correct (if everything in the cell corresponds to its condition) or phenotypically incorrect, not different from mutations (if there is no correspondence to the condition). Although it does not take place at the level of DNA changes, but at the level of its maintenance, yet the phenomenon is demonstrated very distinctly. Now let us see what happens at the level of DNA. What secured changes, present in it, are those to be regarded as mutations? The brightest, the closest to each one of us, and the most studied example will be the human.

Some time ago there was a sort of "genre crisis" in medical genetics. For many centuries everything was accurate and "absolutely clear" - there are some hereditary diseases and mass pathologies. The former included the diseases which were clearly inherited and had vivid manifestation - thalassemia, drepancytic anaemia, haemophilia, children progeria - Hutchinson-Gilford syndrome, Duchenne's myodystrophy etc. Meanwhile, even at that time there were some uncertainties due to different localisation of realisation of pathologies (e.g. lungs are predominantly injured during mucoviscidosis, yet pancreas can be injured greatly too) or different degree of damage in the cases of mutations in the same gene. However, it all had a classical explanation - different expressiveness etc. Gradually, the number of hereditary diseases increased and equalled thousands and the possibility of their appearance (the same penetrance) differed more from firmly 

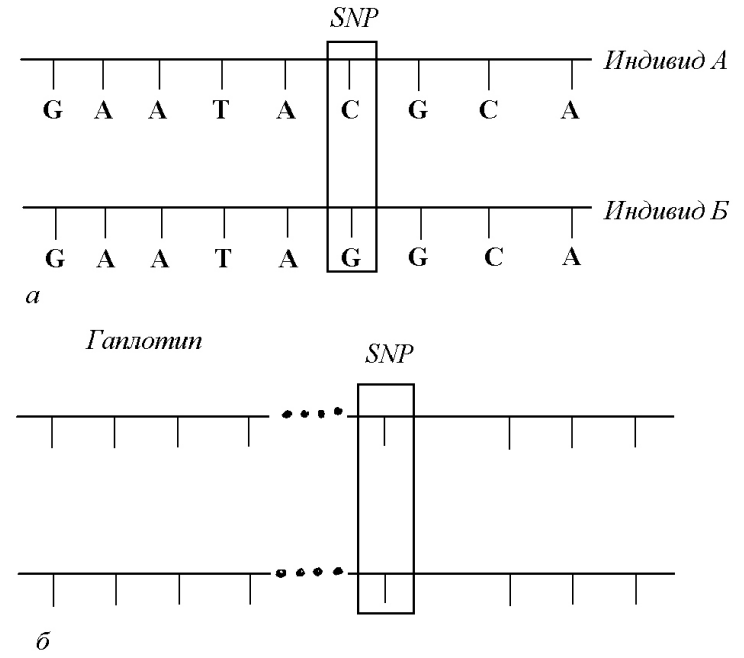

Fig.2 Illustration of what mononucleic polymorphism is [7]

Table 3

Distribution of SNPs in the chromosomes [8]

\begin{tabular}{|c|c|c|c|c|c|}
\hline \multirow{2}{*}{$\begin{array}{l}\text { Chromo } \\
\text { somes }\end{array}$} & \multirow[b]{2}{*}{ Length, b.p. } & \multicolumn{2}{|c|}{ SNPs total } & \multicolumn{2}{|c|}{ TSC SNPs } \\
\hline & & SNPs & $\begin{array}{l}\text { b.p. } \cdot 10^{3} \\
\text { on SNP }\end{array}$ & SNPs & $\begin{array}{l}\text { b.p. } \cdot 10^{3} \\
\text { on SNP }\end{array}$ \\
\hline 1 & $214,066,000$ & 129,931 & 1.65 & 75,166 & 2.85 \\
\hline 2 & $222,889,000$ & 103,664 & 2.15 & 76,985 & 2.90 \\
\hline 3 & $186,938,000$ & 93,140 & 2.01 & 63,669 & 2.94 \\
\hline 4 & $169,035,000$ & 84,426 & 2.00 & 65,719 & 2.57 \\
\hline 5 & $170,954,000$ & 117,882 & 1.45 & 63,545 & 2.69 \\
\hline 6 & $165,022,000$ & 96,317 & 1.71 & 53,797 & 3.07 \\
\hline 7 & $149,414,000$ & 71,752 & 2.08 & 42,327 & 3.53 \\
\hline 8 & $125,148,000$ & 57,834 & 2.16 & 42,653 & 2.93 \\
\hline 9 & $107,440,000$ & 62,013 & 1.73 & 43,020 & 2.50 \\
\hline 10 & $127,894,000$ & 61,298 & 2.09 & 42,466 & 3.01 \\
\hline 11 & $129,193,000$ & 84,663 & 1.53 & 47,621 & 2.71 \\
\hline 12 & $125,198,000$ & 59,245 & 2.11 & 38,136 & 3.28 \\
\hline 13 & $93,711,000$ & 53,093 & 1.77 & 35,754 & 2.62 \\
\hline 14 & $89,344,000$ & 44,112 & 2.03 & 29,746 & 3.00 \\
\hline 15 & $73,467,000$ & 37,814 & 1.94 & 26,524 & 2.77 \\
\hline 16 & $74,037,000$ & 38,735 & 1.91 & 23,328 & 3.17 \\
\hline 17 & $73,367,000$ & 34,621 & 2.12 & 19,396 & 3.78 \\
\hline 18 & $73,078,000$ & 45,135 & 1.62 & 27,028 & 2.70 \\
\hline 19 & $56,044,000$ & 25,676 & 2.18 & 11,185 & 5.01 \\
\hline 20 & $63,317,000$ & 29,478 & 2.15 & 17,051 & 3.71 \\
\hline 21 & $33,824,000$ & 20,916 & 1.62 & 9,103 & 3.72 \\
\hline 22 & $33,786,000$ & 28,410 & 1.19 & 11,056 & 3.06 \\
\hline$X$ & $131,245,000$ & 34,842 & 3.77 & 20,400 & 6.43 \\
\hline Y & $21,753,000$ & 4,193 & 5.19 & 1,784 & 12.19 \\
\hline RefSeq & $15,696,674$ & 14,534 & 1.08 & & \\
\hline Total & $2,710,164,000$ & $1,419,190$ & 1.91 & 887,450 & 3,05 \\
\hline
\end{tabular}

Nota Bene: The data on length (b.p.) were obtained from the series of works on genetics, dated September 5, 2001. The density level of SNPs on each chromosome is determined by the number of accessible genomic sequences, included into genomic selection, the depth of overlapping was obtained from TSC of read and cloned overlappings, which are known to be heterozygotes. determined (or strictly determined possibility as in the cases of classical recessives). Now the notion of predisposition occurred. Then the scientists began discussing the problem of hereditary predisposition and the things related to it. As it had happened earlier, extreme cases again made it all "clear" and these extreme cases were given as examples. Yet at that period of time the technique of DNA sequencing shifted from the genome of human to the genome of mankind. And the uncertainty reached its absolute. As it turned out two unrelated humans differ from each other in three million of mononucleotide mismatches, so called single nucleotide polymorphisms - SNPs (Fig.2). Humankind-wise differences in SNPs reach 10 million. The SNPs also include not mononucleotide differences only, but also those, the percentage of which is not less than $1 \%$ in the investigated population. If all the differences were investigated, than one could find more than three million of differences between two individuals, and they would count billions in the whole human population. All chromosomes are filled with them (Table 3). However, SNPs present something, which has been firmly secured by genome of human, comprising the population, as hereditary changes. In order to consider them as mutations in accordance with the classical definition, the only thing required is the influence on phenotype. Stating on the basic considerations, it is evident that as basic hereditary pathologies and predispositions (viewed by medical geneticists as those of "their own" in regards to process and the object) are resulted in the majority of cases by the changes in one gene and of one nucleotide only, then, all this can be regarded as SNP. And then, medical genetics is a particular case of genomic polymorphism. Yet at the time being (if we estimate statistically) the question is put in a slightly different way - is there a possibility of no effect whatsoever on the organism if any change in any base occurs? Earlier this issue was narrowed down to synonymic and non-synonymic replacements. And, of course, non-synonymic replacements were of greater influence on the phenotype. However, nowadays, it is evident that function of genome is determined, to a great extent, by the special structure of DNA, which is important issue for recognition of servicing proteins, RNA-DNA interaction, etc. Stating on these basic considerations we can suppose that mononucleotide re- 
Table 4

Partial list of SNP-related disorders

\begin{tabular}{|c|c|c|}
\hline Disorder & Gene & Reference \\
\hline Asthma & EDN 1 and NOS 1 & $\begin{array}{l}\text { Immervoll et al., } \\
2001\end{array}$ \\
\hline POAC & Microcillin & $\begin{array}{l}\text { Colomb et al., } \\
2001\end{array}$ \\
\hline Systemic sclerosis & Fibrillin 1 & Tan et al., 2001 \\
\hline Lung cancer & MMP-1 & Zhu et al., 2001 \\
\hline Arrhythmias & KCNQ1 & Kubota et al., 2001 \\
\hline Idiopathic arthritis & MIF & Donn et al., 2001 \\
\hline Blood pressure & TAF1 & $\begin{array}{l}\text { Koschinsky et al., } \\
2001\end{array}$ \\
\hline $\begin{array}{l}\text { Gallbladder } \\
\text { cirrhosis }\end{array}$ & MBL & $\begin{array}{l}\text { Matsushita et al., } \\
2001\end{array}$ \\
\hline Diabetes type II & Syntaxin 1A & $\begin{array}{l}\text { Tsunoba et al., } \\
2001\end{array}$ \\
\hline $\begin{array}{l}\text { Systemic lupus } \\
\text { erythematosus }\end{array}$ & Prolactin & $\begin{array}{l}\text { Stevens et al., } \\
2001\end{array}$ \\
\hline $\begin{array}{l}\text { Indigestion } \\
\text { disorders }\end{array}$ & Melanocortin & $\begin{array}{l}\text { Adan and Vink } \\
2001\end{array}$ \\
\hline Migraine & Insulin receptor & $\begin{array}{l}\text { Mc Carthy et al., } \\
2001\end{array}$ \\
\hline Ossification & Npps & $\begin{array}{l}\text { Koshizuka et al., } \\
2002\end{array}$ \\
\hline Lung cancer & $\mathrm{p} 53$ & Biros et al., 2001 \\
\hline Late PD & tau & Martin et al., 2001 \\
\hline
\end{tabular}

Nota Bene: SNPs - single nucleotide polymorphisms; POAc - primary open-angle glaucoma; MMP-1 - metalloproteinase 1 matrix; EDN 1 - endothelin 1; NOS 1 - neutron synthetase 1 of nitrogen oxide; MBL - mannose-binding protein; Npps - nucleotide pyrophosphatase; TAF1 - fibrinolysin inhibitor, activated by thrombin; KCNQ1 - protein of potassium channels; MIF macrophage inhibition factor; PD - Parkinson's disease.

placements may cause the whole range of effects on phenotype - from lethal cases to a small value. That is the way it went down after concretizing these "general considerations". Today almost all mass pathologies are specified to some SNPs (Table 4).

Why is it so vividly seen on the examples of proteins studied in detail? Particularly, BRCA1 is one of the key signal-regulatory intercellular proteins. BRCA1 molecule contains app. 30 sites, interacting with almost 30 different proteins, many of which belong to regulatory proteins (Fig.3). Detailed study of both gene and its encoding protein, is defined by the connection (to be more precise, the connection between mutations in it) and very high predisposition to the breast cancer. The connection of BRCA1 SNPs and other disorders in the organism has not been studied enough as literally the whole protein (!) (with all amino acids), encoded by BRCA1, interacts with other proteins, then the polymorphism will affect this sort of interactions. However, BRCAl is nothing more than just an example. Yet the influence of SNPs is universal and may affect all proteins - there is not a single thing in the organism that would function on "its own". All macromolecules interact, mutually interfere, interchange conformationally and perform all other inter-kinds of interactions... Even the detailed studies of structure of enzymes and genes that encode them revealed that SNPs, which have no influence on catalytic activity, may determine the interaction of the enzyme with some other proteins [10]; many synonymic replacements in exons are not compatible with normal RNA progressing [11] etc.

Now a very interesting and unusual situation occurs, this situation is full of uncertainty of any (abstract and theoretic) universal, comprehensive, and inwardly contradictory not even a definition, but a notion of what is considered to be a mutation and what is not. In order for proteins to provide the possibility of existence to the cells, where they are, in fact, located, in compound and highly-dynamic complexes, the coordination of interacting domains, conformational transitions, energy levels of their interactions, etc. they have to be of extreme accuracy. Spatial deviations from the ideal (maximally energy-wise convenient for a particular process) should not exceed the tenth part of angstrom and energy-wise ten kilocalories per mole. Otherwise, the complex systems would fail to function properly pretty soon, which would be the end to everything. To present a vivid illustration of this type of interaction it is possible to provide the example from another area (which has no connection with the area under investigation, yet is a very visual one). Let us take two gear units, produced by two different companies, with identical external parameters (entrance and exit velocity, sizes, weight, etc.); if we dismantle (i.e. inside itself) the gear unit of one company and then put it back again, having switched the gears, then everything would work fine. But if we take a set of gear of one manufacturer and switch them for that of the other manufacturer, then these gear units would not work or would work badly and get broken soon. Every manufacturer projects things in a slightly 


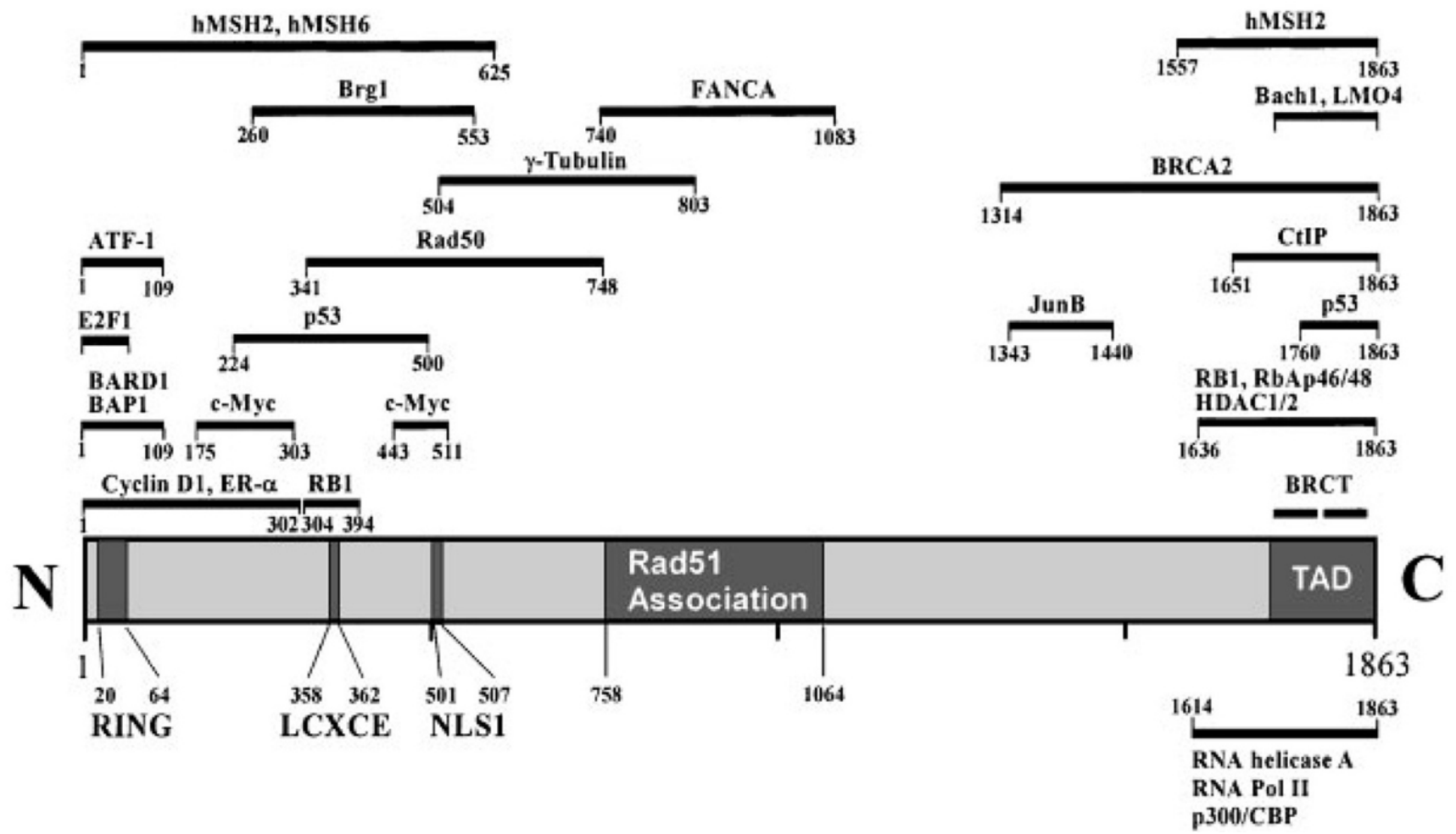

Fig. 3 Interactions of BRCA1 proteins. Scheme, summarising BRCA1 protein-protein interactions. Abbreviations: ATF-1 - activating transcription factor 1; BAP1 - BRCA1-binding protein 1; BARD1 - BRCA1-bound protein 1 of circular domain; BRCT - C-terminal repeat BRCA1; CBP - p265 CREB-binding protein; CtIP - C-terminal binding protein; ER- $\alpha$ - oestrogen $\alpha$-receptor; HDAC1/2 - histone deacetylase 1/2; LCXCE - consensus of binding motif of RB family; NLS1 - primary signal of nuclear localization; RB1 - retinoblastoma 1; RbAp46/48 - retinoblastoma-associated protein, m.w. 46/48 kDa; RING - circular domain (zinc finger); TAD - transcription activation domain [9].

different way than the other (decimal part of the millimetre, axes-wise, gear configuration etc). Of course, molecules are not gears. Spatial and energy interactions between them have got to be many times more precise, so that everything would function properly in the organism. And if any site in any multi-protein complex is changed, then the chain of processes will lead to the externally visible changes in the phenotype. We may now talk about mutations. In case when changes are numerous and all of them are "inter-adjusted", then the system would function successfully. But if we crossbreed these organisms, with all internally compensated changes (but separately for each individual), then the progeny will acquire protein-encoding genes in the changed variant interacting with high-precision. It is pretty often seen in the everyday life, when the children of healthy parents are very unhealthy and it can not be explained by any "recessive" of parents as the parents do not have these "recessives". Simply because their molecules are adjusted in a different way. Yet there may be some harder consequences. Everything in the cell is controlled, including the stability of mobile genetic elements of genome, which are numerous in all eukaryotic specimen (humans included). At disorder of precision of interaction proteins, controlling the activity of mobile elements, the latter are activated, resulting in mass mutagenesis. The following was demonstrated by a series of experiments. Cross breeding of two stable laboratory lines of drosophilae of the second and the third generation (not the first one!!!) revealed numerous mutations and genome instability [12].

Thus, mutations are the changes, that may be assessed in the relation with some initial object, which the phenotypes can be compared to, or within the controlled short reproduction line. In a short succession of generations at least something more precise can be 
Table 5

Distribution of folates in the erythrocytes and DNA methylation status according to MTHFRC677T genotype and low and high content of folates in the erythrocytes [13]

\begin{tabular}{|c|c|c|c|c|c|c|}
\hline \multirow{2}{*}{ Index } & \multicolumn{3}{|c|}{ Low folate erythrocytes } & \multicolumn{3}{|c|}{ High folate erythrocytes } \\
\hline & $\mathrm{C} / \mathrm{C}$ & $\mathrm{T} / \mathrm{T}$ & P value & $\mathrm{C} / \mathrm{C}$ & $\mathrm{T} / \mathrm{T}$ & P value \\
\hline Folate total content, nmole /g Hb & $0.81 \pm 0.20$ & $0.68 \pm 0.27$ & 0.003 & $1.69 \pm 0.70$ & $1.48 \pm 0.27$ & N. S. \\
\hline $\begin{array}{l}\text { Methyltetrahydrofolate of } \\
\text { erythrocytes, } \% \text { from total }\end{array}$ & $98.8 \pm 5.7$ & $67.3 \pm 29.0$ & $<0.0001$ & $99.4 \pm 1.1$ & $69.6 \pm 30.9$ & 0.002 \\
\hline $\begin{array}{l}\text { Methylation status of genomic } \\
\text { DNA, ng metS/ } \mu \mathrm{g} \text { of DNA }\end{array}$ & $\begin{array}{c}64.07 \\
(49.89-81.45)\end{array}$ & $\begin{array}{c}21.93 \\
(14.73-32.45)\end{array}$ & $<0.0001$ & $\begin{array}{c}57.97 \\
(45.60-73.55) \\
\end{array}$ & $\begin{array}{c}57.39 \\
(29.96-109.94)\end{array}$ & N. S. \\
\hline
\end{tabular}

traced. But with something which is correlated with the category of epigenetics, quite often the outside observer can be undistinguished from complete chaos. The clearest (and the most studied) notification is revealed at the level of covalent modification of cytosine, i.e. binding of the methyl group in the fifth position. The exact quantitative determination of methylcytosine content in the general pool of cell DNA (and, thus, the metC to total cytosine ratio) is rather a complex procedure methodically, which has become available in the recent years only. However, once available, this procedure allowed obtaining some very interesting results. Averagely, if we accept some young healthy individual for the average value, then human genome metC contents is averagely $16-17 \%$ of cytosine total [13].

Yet if we take the extreme values, then in normal healthy people (depending on genotype, metabolism of folates, diets, etc) the fluctuations in metC contents in different individuals may be exceeded seven-fold (Table 5). Therefore, some fantastic changes take place in genome, but outwardly it is not reflected at all (the phenotype is the same). There it is, that no matter what mutation region one selects, one has to state on some separate, constantly given, examples, where everything is "as it should be", how fast everything becomes as "it should not be", i.e. indefinite, controversial and so on. There is something wrong in all this, isn't it? All this should-not-be in all of its features testifies about one simple thing - different events have been piled into a number of notions and views on mutations, all of them being placed into Procrustean bed. The situation should meet its end, which is obvious. The question is how to force it. In order to understand "how", to deal with all controversies, inconsistencies, ambiguities, etc, i.e. all the notions the term mutation includes, we are to start from the beginning... from the very beginning. Let us take the humankind as the sample to be compared (it is both most studied one and, apparently, closest to all of us). This "very beginning" is the "starting point" of the individual-to-be (any) and the whole bulk of processes and events following it.

Let us start with ourselves. Over 100 years ago Weissmann introduced the concept of the germ plasma. It was nothing but the idea in the beginning. Gradually experimental data were accumulated and today, succinctly, it looks as follows (Figure 4). Once fertilised, zygote starts dividing. Initially (2-3 days) there are no significant differences between these dividing cells. Later on, they are differentiated, and on day 5-6, only small amount of cells (so called, internal cell mass of blastocyst) preserves its potential of turning into anything - any differentiated or not differentiated cells. In the course of subsequent 3-4 days this part of cells (keeping on multiplying) is divided into two groups. One of them migrates into the internal cavity of blastocyst and takes part in the formation of a yolk bag. The second group forms the embryo. These processes remain active on day 20-21: the group of cells, which initiated the formation of embryo, finishes this process with first morphologically formed elements, while initial germ cells are created out of the group, which participated in the formation of initial yolk bag. Therefore, the predecessors of human germ cells find their beginning not from this human. Both the latter and his germ cells are formed independently from the last group of totipotent cells (apical part of internal cell mass of blastocyst) which still possessed complete differentiation potential. To be more precise, our kids are not really ours. Being simultaneously differentiated cells of future (!) soma ("us"), and subsequent germ route 


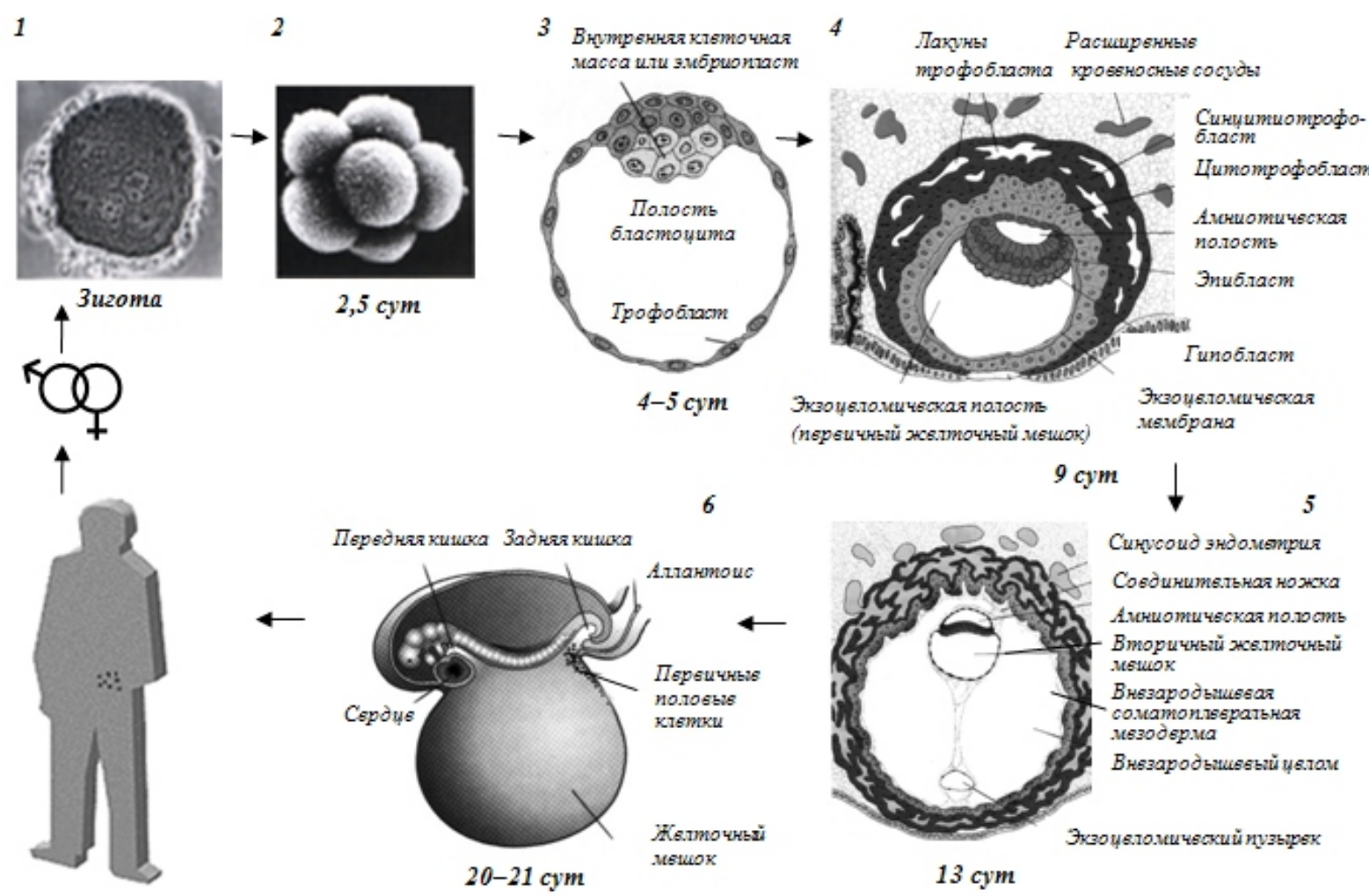

Fig.4 Early stages of human embryogenesis (comprised by [14])

("germ cells predecessors") our kids and we originate from (prior to differentiation) internal cell mass of blastocyst (which in its turn is zygote derivative), i.e. from our parents. The matter is that our children and we are cousins (!!!) genetically. Having been formed in yolk bag on day 20-21, initial germ cells colonise the embryo (soma, according to Weismann). And all this goes on for countless millions of years. Germ route always follows its pattern, with no interruptions, soma being nothing but its temporary carrier and distributor. Consistency of germ plasma has got to be maximal (otherwise, the life will go off its track).

The destiny and the functions of soma are quite different. Soma has got to adjust, conform, react, adapt etc. to the environmental conditions - different, varying, difficult, unfavourable, and so forth and so on. And the wages for all this is inevitable end, in a while. The period of this "while" is specified by the biological time, necessary for development and subsequent trans- fer round of germ plasma. Having all these differences (life task, goal of existence, time of existence, conditions of existence in the turbulent world or in secured soma, etc) all processes, mutations included, in soma and germ plasma can nowise be the same, neither in essence nor in functionality, nor in tasks, put forward by life as phenomenon. Meanwhile, due to historically developed ideas, mutations are evaluated by the events, occurring (spontaneously or induced) in the germ route, moreover, the evaluation takes place not in the latter directly, but via the realisation in soma. Even when the mutations are determined in somatic cells, generally, they are determined by multiplication of such cells in selective conditions, which have hardly anything in common with the things that take place in the organism. Soma is us in the course of decades in the conditions which are impossible to describe, perceive, estimate or even imagine. So, what is going on in soma with the thing, individually perceived differently, but defined as 
mutations? To understand what takes place in soma (i.e. in you and me), let us start with damages in DNA, i.e. something preceding the mutations, something which is neither norm any more, nor the mutation yet, in common opinion. But it concerns common opinion only, as in the essence of the process as well as its realisation (until this process is brought either to norm by reparation or to changed and fixed state, i.e. "common mutation") the damage is the actual mutation in its utmost presentation. The damage of the base blocks the progress of RNA polymerase, and the gene is not read off any more. It is dysfunctional until the damage is repaired. In the case of cell it is phenotypically (but only at the level of cell) indistinguishable from mutation, completely switching off the manifestation of this gene. Certainly it goes on only for the time of damage existence, but rather radically. What is the average number of damages in every human cell? The figure is determined by numerous factors, the first of which (in the chain of the latest events) is the reaction-active products.

The most mass destructive ones are oxygen and its derivatives. This is the very oxygen, the absence of which makes one die in several minutes. Average oxygen consumption by one individual per day is $640 \mathrm{~g}$ (420 1) [15]. Average number of oxygen radicals formed daily in every cell due to breathing is $\sim 6.5 \cdot 10^{10}$ [16]. Quantity-wise (i.e. item-wise) it is manifold more than the total number of all bases of nucleic acids and protein amino acids in a cell, and weight-wise it constitutes $0.1 \%$ of the average cell weight. Total weight of all reaction-aggressive products, formed in the cell during its absolutely normal and vital activity daily, exceeds the total weight of all macro- and non-macro molecules of the cell [17]. And no matter what ultra-super-new perfect protection systems (i.e. at the level of preventing and avoiding) from these agents exist, some part of these agents will overcome the protection and result in damaging everything, including genome. In the course of time there have been many assumptions on the issue. Gradually the methods have improved and correct quantitative data have been accumulated. Oxidative damages of DNA in the cell are the most studied ones. They are diverse enough and their total number is $0.5-2 \cdot 10^{6}$ of damages per genome of every cell per day [18]. The level of damages is signifi- cantly higher (up to 2-fold) in mitochondrias [19]. But oxidative damages constitute only a part of the whole pool of DNA damages in the cell. The other types of damages are studied less. However, their contribution proves to be rather valuable in the course of studies. For instance, depurinisation amounts to $10^{4}$ per nuclear DNA of every cell daily [20]. Great is the contribution of other damages as well. Extrapolating all the abovementioned, one has all the grounds for accepting the level of damages of nuclear DNA of every cell as app. $10^{7}$ daily. And it concerns the whole life. Mutations (as commonly perceived) occur, even if we do not consider the whole time but their division periods only, and take fast-dividing cells (e.g. blood cells, on the way of their formation from initial stem cell to the differentiated one, which enters the blood flow), with the frequency (averaged a lot) $\sim 10^{-7}$ per gene, i.e. (taking into account the number of genes in human body is $\sim 35000$ -40000 ) it is at least 10-times (!) less frequent.

Factor, determining the quantities of damages, is the damage protection system. Efficiency of the protection system is controlled both evolutionarily and functionally. The comparison of these systems reveals significant differences depending on the kinds of mammals. Generally, it could be expected - different evolutionarily distant taxons can not be the same. However, unexpected is the fact that (and contradicting early research) the activity of systems, preventing DNA damages, does not change throughout the lifetime (Table 6).

It can testify in favour of the existence of some programmed level as the level of systems, preventing DNA damages, determines the level of damageability proper. It is noteworthy that the number of damages and the level of damageability are not the same. If we speak not about the number of damages per time unit, but about the level, i.e. about certain constant number of DNA damages, it is going to be quite a different notion. Damages are repaired in some time. They are repaired by the other system - not the system of preventing DNA damages but the reparation system. The level of damages will look like some balanced value between the damageability rate and the reparation rate.

Fundamental is the question of what exactly balanced value will be provided by these opposite processes. Will this balanced value be spot-timely, i.e. bal- 
anced only for short periods of time, within which both external and intercellular parameters are actually the same, or will it change due to their changes (which takes place continuously in life)? Will it be balanced in the wide range of external conditions? Direct experiments revealed rapid increase in spot-level of damageability (achieved by intense $\gamma$-irradiation) to restore back to the initial values fast (in several minutes) in a sharp straight line (Fig.5). Restore back to the initial values!

The process is the same in both old and young animals. The situation is absolutely marvellous - the reparation systems are so powerful as to restore the damages, occurring due to external disturbance, in a sharp straight line. However, later on, having achieved certain primary level, the reparation slows down the restoration and is "maintaining the same level". What if one tried to help the cell to decrease the level of damages (i.e. their balanced number in genome)? Seemingly, the cell should profit from it. In reality it takes place "quite the contrary". The introduction of additional genes, encoding the reparation enzymes, into the normal cell and the increase in their quantities results in negative consequences. For example, over-expression of reparation enzymes of alkyl-N-purine glycosilase or DNA-polymerase $\beta$ resulted in genome instability, and, consequently, in the occurrence of instable phenotype [21]. It could happen in one case only, the cells require a certain level of damages of their genetic material to function properly. Though seemingly impossible to be considered, this assumption can be proved by direct experiments. The first step forward was made after the daily number of damages occurring had become known. This first step was actual admission of the fact that oxidative DNA damages are "normal cell metabolism" [18]. It turned out to be harder on the assumption on the role of genome damages during normal cell metabolism. To be strictly consistent, the role of damages derives from their direct effect on the expression. Once the gene is damaged, the reading-off it stops at the damaged base. That is, the damage switches the gene off, temporarily, until the reparation deals with the damage. In its phenomenology, switching off the gene - in this case due to the damage of its base - and its subsequent (in some time) switching on (by reparation, restoration after the damage) is nothing but regulation. Therefore,
Table 6

Frequency of gene amplification in control or $m I C A D^{*}$-expression of HCT116 and L929 cells [27]

\begin{tabular}{|c|c|c|c|}
\hline \multirow[t]{2}{*}{ Tissues } & \multirow{2}{*}{$\begin{array}{l}\text { Anti-oxidative } \\
\text { enzymes }\end{array}$} & \multicolumn{2}{|c|}{$\begin{array}{l}\text { Enzymatic activity, relative } \\
\text { units per } 1 \mathrm{mg} \text { of protein }\end{array}$} \\
\hline & & Young mice & Old mice \\
\hline \multirow[t]{4}{*}{ Liver } & Catalase & $4.65 \pm 0.17$ & $4.56 \pm 0.09$ \\
\hline & Gluthationperoxidase & $7.16 \pm 0.60$ & $8.36 \pm 0.28$ \\
\hline & $\begin{array}{c}\text { Mn-superoxide-dismut } \\
\text { ase }\end{array}$ & $11.52 \pm 1.32$ & $12.12 \pm 0.31$ \\
\hline & $\begin{array}{c}\text { CuZn-superoxide-dism } \\
\text { utase }\end{array}$ & $192.53 \pm 20.23$ & $174.28 \pm 16.19$ \\
\hline \multirow[t]{4}{*}{ Heart } & Catalase & $0.42 \pm 0.07$ & $0.51 \pm 0.02$ \\
\hline & Gluthationperoxidase & $0.40 \pm 0.06$ & $0.61 \pm 0.02$ \\
\hline & $\begin{array}{l}\text { Mn-superoxide-dismut } \\
\text { ase }\end{array}$ & $63.08 \pm 1.95$ & $68.04 \pm 3.69$ \\
\hline & $\begin{array}{c}\text { CuZn-superoxide-dism } \\
\text { utase }\end{array}$ & $66.92 \pm 0.33$ & $73.20 \pm 3.91$ \\
\hline \multirow[t]{4}{*}{ Brain } & Catalase & $0.29 \pm 0.03$ & $0.34 \pm 0.06$ \\
\hline & Gluthationperoxidase & $0.86 \pm 0.12$ & $0.90 \pm 0.07$ \\
\hline & $\begin{array}{c}\text { Mn-superoxide-dismut } \\
\text { ase }\end{array}$ & $13.76 \pm 1.02$ & $18.01 \pm 1.34$ \\
\hline & $\begin{array}{c}\mathrm{CuZn} \text {-superoxide-dism } \\
\text { utase }\end{array}$ & $43.31 \pm 1.69$ & $46.53 \pm 4.75$ \\
\hline
\end{tabular}

Nota Bene: The activity of different anti-oxidative enzymes was measured by extraction of tissues from young (6-7-month) and old (26-28-month old) female mice of C56B $1 / 6$ cell line.

it is possible to suppose that the damage of the bases is of some regulatory meaning. Its essence and nature arise from the analysis of some experiments on human cells. Age-dependent proteins are present in brain cells (the work was performed on autopsy material). This dependence relies on the fact that the number of one type of proteins decreases with time, that of the second type remains the same, and that of the third one increases. The study on the level of their damages revealed the promoters of these proteins to be damaged and to be repaired in strict accordance to what "should be" during ageing (Fig.6). In the essence of the whole chain of processes it is the regulation, but very unusual to us. Detailed investigation on this issue revealed it to be conditioned by the corresponding levels of DNA damages in the promoter regions and the reparation, matching them (Fig.7). As in this case the promoters were treated with the agent, causing the damage of the 

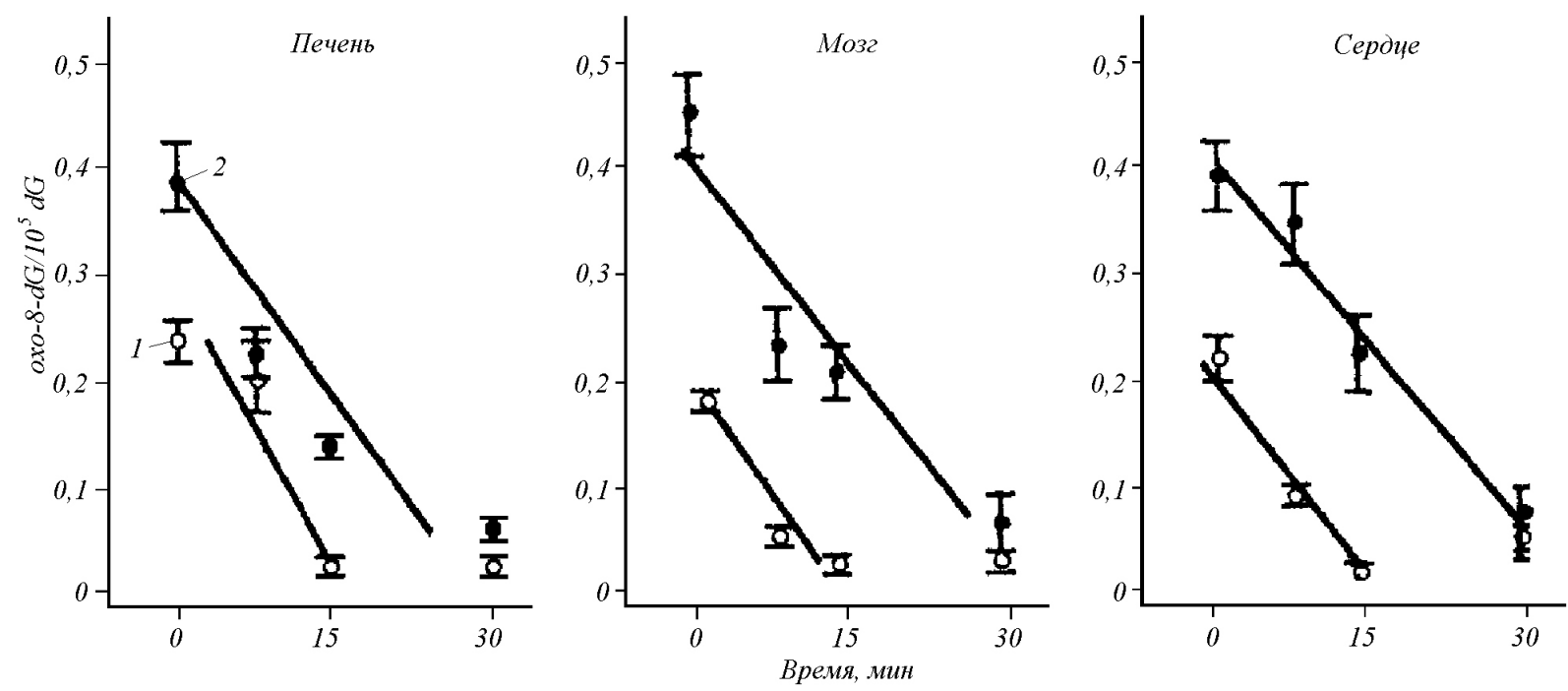

Fig. 5 Influence of age on elimination of oxo-8dG from nuclear DNA after acute $\gamma$-irradiation of the whole organism. Young (1) and old (2) female mice of C57BL/ 6 were subjected to $\gamma$-irradiation, $2 \mathrm{~Gy}$, immediately after 7, 5, 15, and 30 min after irradiation; nuclear DNA was isolated from liver, brain, heart. Every value represents the level of oxo-8-dG, caused by $\gamma$-irradiation, i.e. oxo-8-dG level in tissues, not subjected to $\gamma$-irradiation, was subtracted from the level of oxo-8-dG, obtained after irradiation. Every value is the average value obtained for six mice \pm SEM. Velocity of oxo-8-dG elimination from nuclear DNA was calculated using Microsoft Excel, which allows obtaining the straight line, coming out of the point of the biggest damage (time 0 ), coming through the temporal points till it reaches oxo-8-dG/10 $\mathrm{dG}$ of base line. Then Microsoft Excel makes the inclination of the line and these lines are presented in Fig. Elimination velocity of oxo- $8-\mathrm{dG} / 10^{5} \mathrm{dG}$ was $0.113 \pm 0.049$ against $0.109 \pm 0.025$ oxo- $8-\mathrm{dG} / 10^{5} \mathrm{dG}$ per $1 \mathrm{~min}$ for livers of young and old mice respectively; $0.134 \pm 0.033$ against $0.086 \pm 0.009$ of oxo- $8-\mathrm{dG} / 10^{5} \mathrm{dG}$ per $1 \mathrm{~min}$ for brain of young and old mice respectively; 0.118 young and old mice respectively $0.100 \pm 0.029$ of oxo- $8-\mathrm{dG} / 10^{5} \mathrm{dG}$ per $1 \mathrm{~min}$ for heart of young and old mice respectively; velocity of elimination of oxo- $8-\mathrm{dG} / 10^{5} \mathrm{dG}$ for young and old mice was compared statistically using Student's test. No statistically reliable differences were obtained for all three tissues. However, the levels of oxo- $8-\mathrm{dG} / 10^{5} \mathrm{dG}$ were higher $(\mathrm{p}<0.001)$ in old mice than in young mice, in all temporal points, except for 30-min point of all tissues, and the point, corresponding to $7.5 \mathrm{~min}$ for liver [18]

bases outside the cell (i.e. in strictly equivalent, controlled conditions) and then (again the same) were introduced into the identical cells, different degree of reparation (and consequently different balanced level of damage) depended on the specificities of promoters (primary sequence, formed spatial structures etc). Absolutely new and very interesting system of the regulation of gene activity emerges. The majority of genes in the cell are constitutively expressed. They do not have the sites for interactions with regulatory proteins. But genetically programmed nucleotide sequence predetermines damageability level of these sequences. Constitutive genes turn out to be regulated, though via absolutely different mechanism. This is the way for new concepts to occur: damageability of genome as natural mass mechanism of its activity regulation; regulations via different damageability due to different primary sequence. Let us take a look at what is going on at the level of realised mutations, i.e. changes fixed in ge- nome of somatic cells. The changes in primary DNA sequence, i.e. at the role of mutations in soma - in you and me. The first thing to dwell upon is the fact that the special phenomenon - dynamism of mutations - exists in soma. The essence of dynamism is that the mutations (fixed, classical ones) not only occur but also disappear, eliminate. There are two ways for this elimination: the first one is commonly known and is determined by the elimination of cells with mutations. For this purpose, the mutation should activate the processes, causing the elimination of cell, bearing it. To perform the elimination there is apoptosis, immune surveillance, autophagy etc. Everything seems to be clear here. Though the quantitative side of this self-purification from mutations is so high that deserves to be the topic for separate discussion. Throughout human life-time total weight of cells, eliminating in his body, exceeds the "stable" (i.e. average $70 \mathrm{~kg}$ - average body weight), but actually some balanced body weight 100 -fold [17]. But this is 


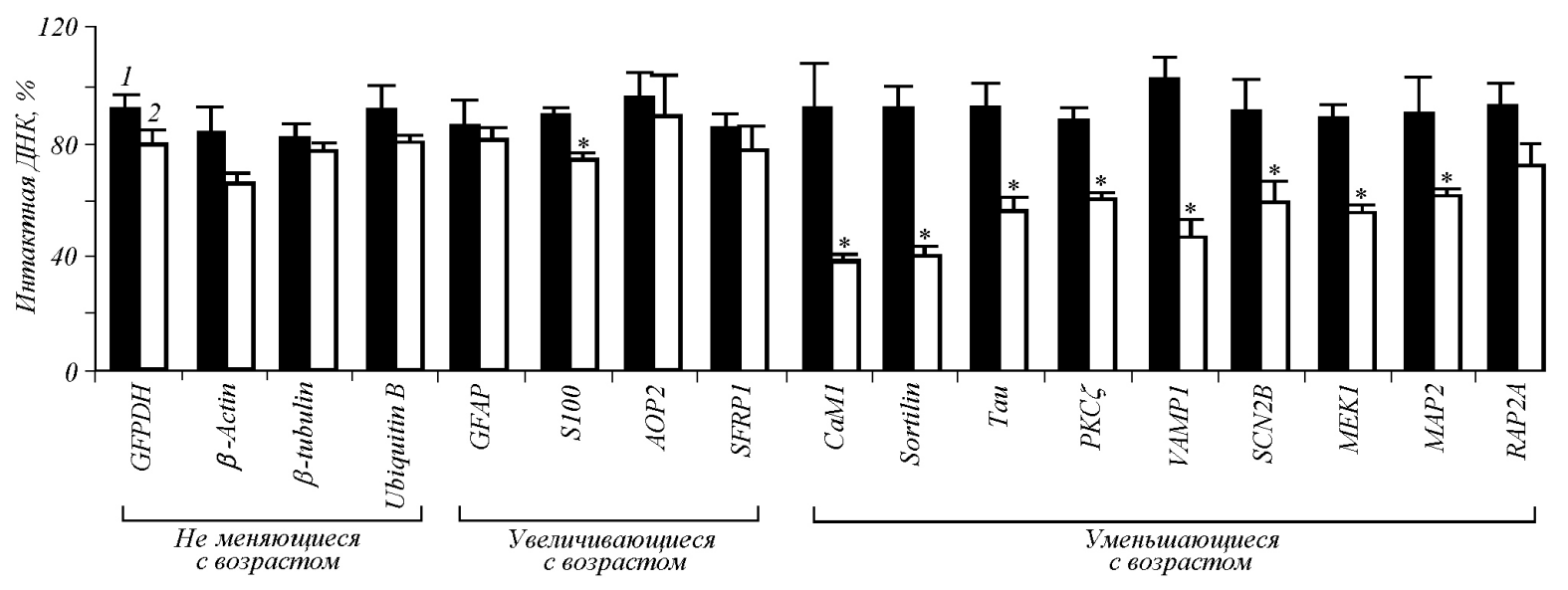

Fig.6 "Increased sensitivity to oxidative damages of DNA promoters of genes, activity is age-down-regulated. Human culture of cortical neurons was incubated in the presence or absence of $100 \mu \mathrm{M} \mathrm{H}_{2} \mathrm{O}_{2} / 20 \mu \mathrm{M} \mathrm{FeCl}_{2}$ in the course of 12 hours, and then damage of DNA promoter was determined. The values are the average values of \pm s.d., $n=3$. Stars indicate $p<0.05$ regarding untreated samples; $p<0.001$ for the groups of genes with promoters, activity of which decreases with age in regards to the promoters of genes, activity of which does not depend on the age, or genes, activity of which increases with age" [22]

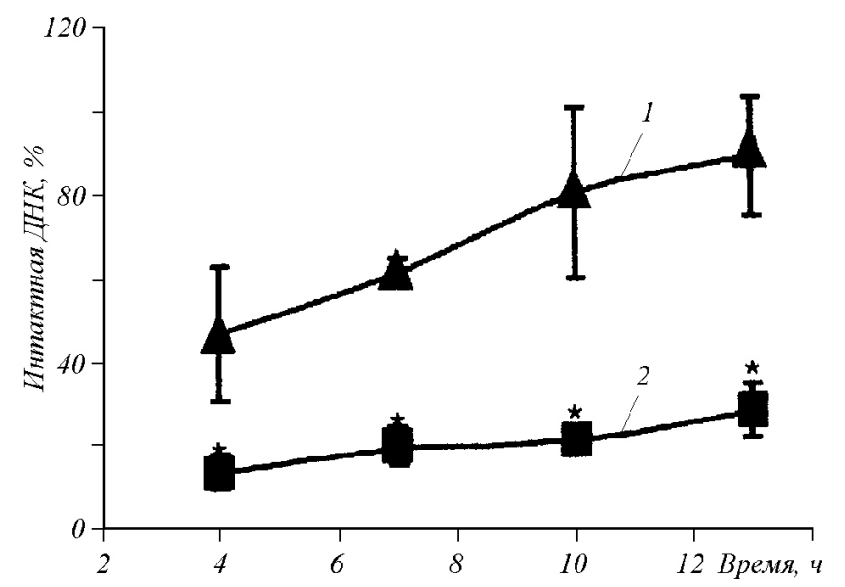

Fig.7 "Damage and reparation of DNA promoters of b-tubulin and calmodulin 1. Reporter plasmids, damaged in vitro with $\mathrm{H}_{2} \mathrm{O}_{2}$, were transfected, then in each promoter damaged DNA sequence was determined. The values are indicated in regards to undamaged transfected reporter DNA, and are the average value of three changes $(n=3) \pm$ s.d. (standard fluctuation). Stars indicate $p<0.05$ in regards to b-tubulin" [22]

quite another topic. "Generally speaking" everything is "clear", mainly.

The second way to eliminate the mutations is unusual. This is the way to eliminate the mutations from the cells, preserving the latter, which is obvious from the following example [23]. The contents of different types of mutations were studied in completely charac- terised sequence in different tissues of transgenic mice. Young mice, 3.5-month-old, (by this time all their tissues and organs were formed) and old (decrepit) mice, 32-month-old, (specific mice lifetime is 3 years) were used in this experiment. The detailed study on the mutation spectre revealed that 2 mutations of 4 discovered in the brain (i.e. where cell substitution is minimal, and with no damages is even insignificant) of young mice disappeared completely by 32 -month-old age. One type of mutations disappeared in the spleen (cell renewal in it takes place regularly) (Fig.8). This sort of purification from mutations resulted in either no increase in mutations with age or its being insignificant in some tissues (Fig.9).

Therefore, both the level of damages and the level of fixed mutations (i.e. mutations, classical according to all the views) are maintained in the organism (soma) at the level, required by it (organism). Required level! For the misbalance towards any side (i.e. to any, either higher or lower level) turns out to be harmful and leads to negative consequences. As it has been mentioned above, it has been proven by the experiments. Almost the major part of genome is involved into the reparation, i.e. in the aggregation of processes, determining the level of mutations, to some extent. Thus, in the case of bacteria, their contribution is $30 \%$ of genome total, exceeding 1000 of genes in the absolute number [25]. 
3,5 м еся ия а

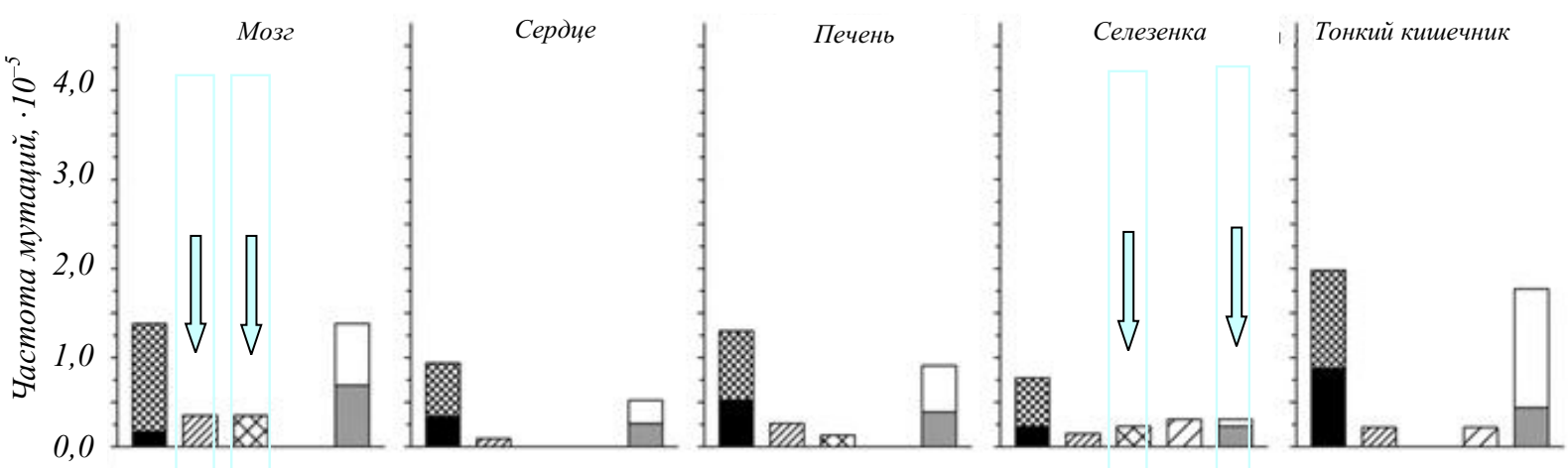

32 месяиа
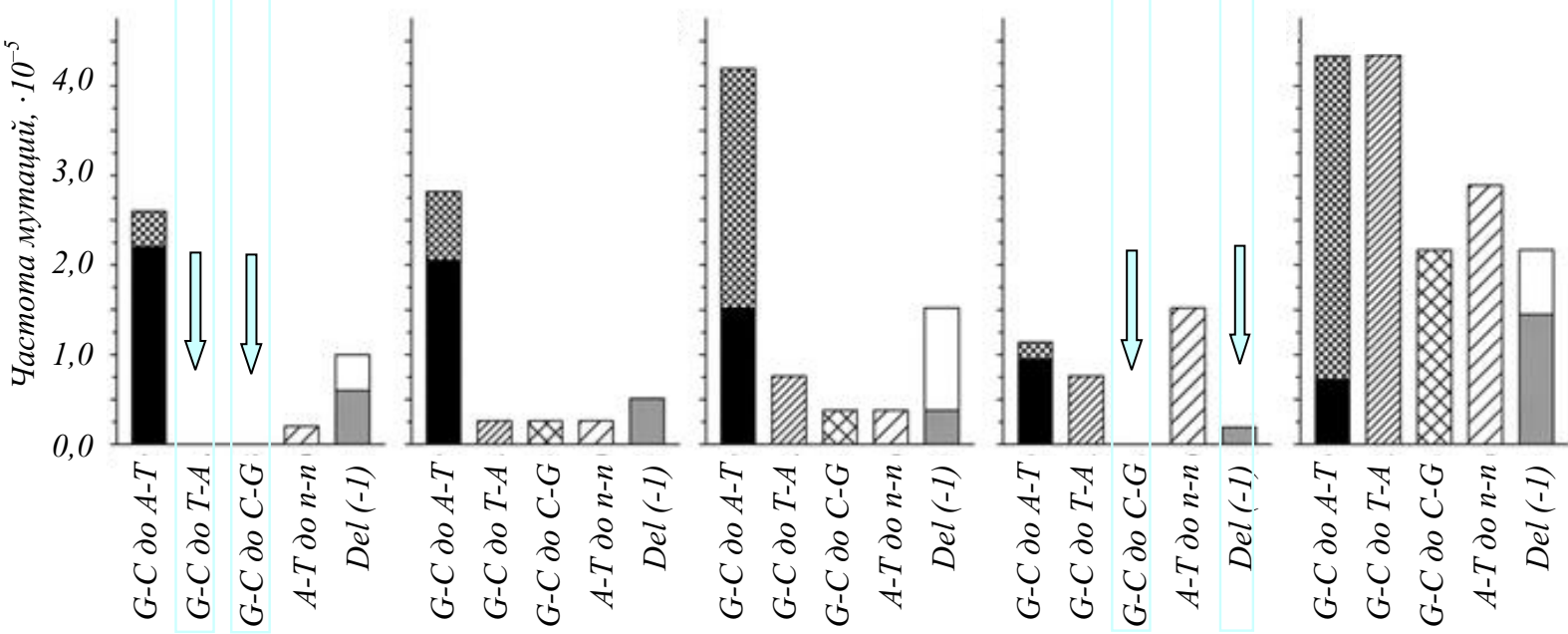

Fig. 8 "Point mutation spectra for reporter gene lac $Z$ in brain, heart, liver, spleen, and small intestines in young ( 3.5 month) and old ( 32 months) mice. The columns represent the frequency for each type of mentioned point mutations. Black part of the column of G:CA:T shows the part of mutations, occurring in CpG-sites, grey part - in Del(-1)-columns indicate the frequency of each mutation, taking place in the repeated sites, e.g. sequence of three or more nucleotides. Corrections have been made for the repeated mutations" [23]

In mammals it is more precise (and, as one can suppose, much more diverse).

In the case of spot mutations (e.g. nucleotide substitutions) their regulatory function remains unknown (and for the sake of justice, it has to be said that it has never been studied). Only something special can be distinguished - tautomeric passages. Tautomeric changes in bases can not be repaired. By no means and in no way. They are regulated by the condition of DNA: spatial structure, dependent on the primary sequence, DNA interactions with proteins, small molecules, etc. For some reason no attention is paid to the fact that the form of mutagenesis, regulated by the cell, exists in the latter continuously. Lots of experimental material have been accumulated at the level of larger changes and their regulatory significance is manifested vividly. Vividly enough not to be ignored. However, being described, it is masked by other terminology (like it is valuable enough to change the meaning). Chromatin diminution in Ascaridae was described the first in this sense (i.e. regulatory role of mutations), being strictly functional and precision elimination of a part of genetic material in soma after division of the germ route into its own new continuation (germ route) and dead end - soma. Later on, diminution was discovered in other organisms as well. Moreover, it 


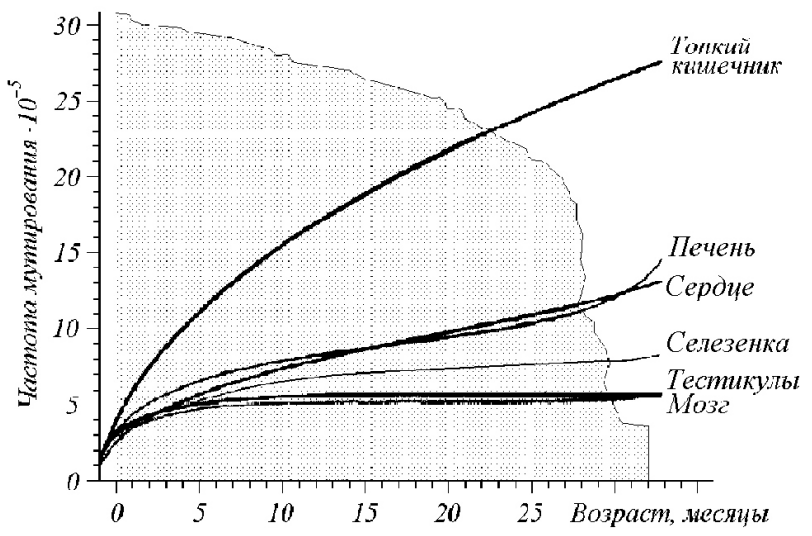

Fig.9 Frequency of reporter gene lac $Z$ in brain, heart, liver, spleen, and small intestines in transgenic mice of 60 line (Dolly et al., 2000, Martin et al., 2001; Geise et al., 2002). Lines are presented as "manually drawn" curves, corresponding to the average mutation frequencies in different age groups. Regions marked in grey represent the curve of mice survivability, corresponding to $100 \%$ at birth and falling down to $50 \%$ at 26.5 months" [24]

was shown to be in larger amounts, compared to Ascaridae. Thus, in ciliates in some cases, elimination reaches up to $95 \%$ of genome, compared to the one preserved in germ route [26].

Diminution is the most reliable form of regulation. What is absent can not be revealed, activated, realised illegally, etc. There is no need for special systems of regulation (complete switching off and keeping up to this state), which is obviously profitable for complex signalling pathways. However, it is absolute in mammals only (humans included). 100\% elimination of genome is their specific feature solely, which takes place during erythropoiesis. At certain stages of differentiation, the nucleus is removed completely from the cell in erythrocytes predecessors. On the one hand, this is the way to save the space, necessary for the material, providing oxygen transfer. On the other hand, massive and the largest cell population, constantly formed and disappearing, potentially maximally damaged (oxygen transfer, i.e. its continuous consumption, storing, and delivery) would be of extreme threat of massive continuous overall malignisation, if it had the nucleus. No powerful immune surveillance would be enough to stop it. In this respect the regulation is also anti-oncogenic (and thus absolute).
Puffs of diptera were the next discovery. The puffs are basically formed on the chromosomes in the sialaden cells. They are mediated with the sectors of normal size and constitute manifold (more than 1000 -fold in their extremes) amplified genes, whose function is to be strengthened. In these cases, the regulation of gene activity is achieved by their corresponding multiplication. The formation of puffs as a type of regulation triggered new research. Heat shock proteins (preceding chaperons) were discovered via the occurrence of the new puff in drosophila at rapidly increased temperatures. The amplification in mammalian cells was discovered under the influence of toxic substances (starting with methotrexate) as the response, leading to the increase in producing defensive proteins. Yet "spontaneous" amplification of different genes is natural for the mammalian cells. Actually, the term spontaneous is neither synonymous to chaotic nor all of a sudden. Spontaneous is when the reason is unknown... unknown, but not absent. So far, the scientists do not know how to study the amplification in mammalian organisms directly. They can only determine it in cell culture. It can neither be neglected nor statistically the same for different genes. Thus, for two human genes, background differences of the levels of amplification between different cell lines were over 170 times one gene-wise and 3 times higher another gene-wise, as for these genes within one and the same cell line -120 times higher for one pair and app. 4.5 times for the other one (Table 7).

Amplification is typical "large change in genome with apparent phenotypic manifestation". According to classical definitions these are the mutations with regulatory functions.

Special class of mutations is distinguished on the basis of combinatory amplification-recombination mechanism. The first one to be mentioned (detection time-wise) is magnification. Any repeats are inclined (due to their identity according to the primary sequence) to recombinational chipping off and, as one of the consequences, to losses. Ribosomal genes in genome are multi-copy ones. Due to this fact their number may decrease in generations. In such cases, as it has been initially discovered in drosophila, the mechanism of their restoration is switched on in the germ route cells. At a certain stage, remaining part of genes of ri- 
bosomal DNA is chipped off legally from the chromosome, amplified in this autonomous condition, and then integrated back into the chromosome (where it has got to be, homology-wise). Thus, the number of necessary genes is restored in the generative line.

Similar mechanism is the ground for a qualitatively new phenomenon - the formation of new genes (not present in the germ route, and, therefore, in germ cells as well) and "on-demand genes".

A well-known example of the formation of new genes in soma (not present in the germ route and non-incorporating into it after their formation in soma) is the genes of antibodies.

Due to the special mechanism, i.e. so called, $\mathrm{V}(\mathrm{D}) \mathrm{j}$-recombination in the line of B-lymphocytes there may be (and actually takes place) the formation (almost endless in its diversity) of new genes, encoding antibodies to various antigens. These genes are not present in the germ route, they occur in soma de novo. If necessary, one more mechanism gets involved clone selection, and the cells, having this new gene, are multiplied intensively. This is a good sign of the fact that insufficient frequency of mutations in the organism can not be put forward as the objection to their functional load. Genes of antibodies can serve a good example of the formation of any amount of new necessary genes in soma (not anywhere but where it is really needed), which are not present (and could not be present) in germ route genome. Yet antibodies are far from being just the element of immune defence. The discovery of abzymes - catalytic antibodies - reveals that their functions may be much broader. At the same time these catalytic antibodies may be as complex as possible. For instance, DNA-hydrolysing antibodies to native DNA (they were discovered in blood serum of patients with systemic lupus erythematosus) are metal-dependent (i.e. complex functioning) endonucleases [28]. As $\mathrm{V}(\mathrm{D}) \mathrm{j}$-recombination is known to spread on the events, occurring in not immune system solely, and there are some other recombination systems, then the discovery of the formation of new genes in soma is logical to be the matter of time.

The other example (not yet described in mammals) is the occurrence of "on-demand genes", i.e. the phenomenon under discussion since Lamark's times as the problem of "inheritance of the acquired features". In
1988-1991, the authors of [29, 30] described the first trustworthily reproducible example of the occurrence of the feature (characteristic) "needed" with subsequent inheritance. These experiments revealed that reverse mutations in mutant gene $\beta$-galactosidase take place more often at the content of cells with these mutations in the medium, where the only nutrition source was lactose, than at average genome-statistic content. This frequency is also higher than in the current gene (i.e. in the same mutant gene $\beta$-galactosidase with return to the normal state) compared to the frequency of mutations on rich nutrition substrates. Detailed study on this issue revealed that its efficiency is dependent on the degree of completeness of amplification and recombination mechanisms (Fig.10).

To achieve the maximal efficiency of such events, the gene has got to be flanked by the repeats (ideally to be on the transposition element), and the cell has got to contain the proteins, providing both DNA amplification and its recombination [31]. In such combination the probability of "necessary" mutation increases 1000 -fold. Not the general level of mutations, but the level of mutations of a current cell. The mechanism of such preference is not clear yet. Basically, it comes down to the activation of amplification and recombination. So far, this phenomenon is most studied in bacteria. However, all necessary elements for this procedure are present in eukaryotes generally, and humans in particular, incomparably better, more often, abundant, than in bacteria. Eukaryotic genome consists of the repeats and various potentially (and at some conditions actually) mobile elements. Principally important for this concept is the fact that variants of repeats in the genome are way too numerous (in the number of elements of repeats, their total number, i.e. lengths) and all of them (all of them!) differ from random distribution manifolds [32]. They are supported by the selection in the current form, they should be like that in order to perform their function. The brightest, the most evident, the most wide-spread function of the repeats is the provision of the recombination events as well as participation in them. Moreover, almost all human genes are flanked with repeats (Alu mainly).

The regulatory role of genome reorganisation (though very limited yet) is already admitted practically for all the living beings (Table 8). 
Frequency of gene amplification in control or mICAD*-expression of HCT116 and L929 cells [27]

\begin{tabular}{|c|c|c|c|c|c|c|c|c|c|}
\hline \multirow[b]{2}{*}{ Type of cells } & \multirow[b]{2}{*}{$\begin{array}{c}\text { Irradiation } \\
\text { dose, Gy }\end{array}$} & \multicolumn{4}{|c|}{ PALA selection (amplification of cad gene) } & \multicolumn{4}{|c|}{ MTX selection (amplification of dhfr gene) } \\
\hline & & $\mathrm{PE}, \%$ & $\begin{array}{l}\text { LD50, } \\
\mu \mathrm{M}\end{array}$ & $\begin{array}{c}\text { Total quantity } \\
\text { of selected } \\
\text { cells, } \cdot 10^{6}\end{array}$ & $\begin{array}{l}\text { PALAr, } \\
\text { frequency• } \\
\quad 10^{-5}\end{array}$ & $\mathrm{PE}, \%$ & $\begin{array}{l}\text { LD50, } \\
\mu \mathrm{M}\end{array}$ & $\begin{array}{c}\text { Total quantity } \\
\text { of selected } \\
\text { cells, } \cdot 10^{6}\end{array}$ & $\begin{array}{c}\text { MTXr, } \\
\text { frequency• } \\
10^{-5}\end{array}$ \\
\hline HCT116/control & - & 45.3 & 31.4 & 4.5 & 5.54 & 42.0 & 17.5 & 15.6 & 0.046 \\
\hline HCT116/mICAD & - & 64.7 & 15.0 & 1.5 & 27.4 & 41.0 & 13.3 & 15.6 & 0.25 \\
\hline HCT116/control & 3 & 59.3 & 31.4 & 2.4 & 8.50 & 13.4 & 17.5 & 14.3 & 0.21 \\
\hline HCT116/mICAD & 3 & 66.0 & 15.0 & 0.6 & 41.7 & 18.0 & 13.3 & 11.5 & 1.01 \\
\hline L929/control & - & 47.3 & 21.3 & 20 & 0.032 & 47.3 & 31.0 & 10 & 0.15 \\
\hline L929/mICAD & - & 55.5 & 9.9 & 3 & 21.3 & 55.5 & 16.7 & 12 & 0.81 \\
\hline L929/control & 4.5 & 22.8 & 21.3 & 4.8 & 3.66 & 22.8 & 31.0 & 4.8 & 10.5 \\
\hline L929/mICAD & 4.5 & 11.8 & 9.9 & 2.4 & 81.6 & 11.8 & 16.7 & 3 & 37.4 \\
\hline
\end{tabular}

Nota Bene: PE - cloning effectiveness; $\mathrm{LD}_{50}$ - the dose of $50 \%$ growth cells in the presence of the inhibitor; PALA ${ }^{\mathrm{r}}-$ PALA-stable clones; MTXr - MTX-stable clones.

Yet mentioning this role, the most apparent thing is not noted - all this takes place at the level of soma and not in the germ route.

The unique mechanism (almost not studied yet) which can both perform regulatory functions and create qualitatively new information, is the mutations with the shift of the reading frame $(+1,+2$, i.e. the insertion of one or two additional nucleotides, or $-1,-2$, i.e. deleting one or two nucleotides). At RNA level, the formation of new information is well known and studied. It is due to the fact that at the stage, suitable to perform the function (at least in eukaryotes), the synthesised RNA is inadequate in primary sequence to its matrix - gene where transcription was initiated. Besides familiar splicing, during which the information, read off the gene, "is gathered" by fragments and provides the synthesis of different proteins at different alternative variants, there is also the shift of reading frame (due to RNA-polymerase slipping) and editing. All this is suitable for RNA. But for DNA it is not accepted at all. Only regulatory role of mutations with the shift of reading frame is slowly introduced (and rather carefully) at the level of genome. Thus, adhesion antigen, which switches back and forth with the frequency of $10^{-3}-10^{-4}$ according to the phase-variable principle (i.e. both ways: expressed - not expressed) has been discovered in mycoplasma. Such switching back and forth is realised due to the shift of the reading frame. It may result in the formation of stop-codon or the occurrence of a new reading frame, i.e. RNA, which has to be translated into a new protein, is read off $[34,35]$.

Both the overcoming of mutation with the shift of reading frames, and the formation of such mutations can be regulated. Thus, special 8-member sequence (CGCGCGCG), which is a hot-spot of mutation - 2 shifts of reading frame - is described in genome of eubacteria. Such double shift is provided (by skipping $8^{\text {th }}$ guanine of the hot-spot) by special holoenzyme of DNA-polymerase III, i.e. the protein, specifically encoded in genome (and regulated) for this purpose [36].

In eukaryotes, this system of regulation (i.e. with the shift of the reading frame and its overcoming) acquires more complicated character. In yeasts the complex system of regulation of metabolic processes, with the participation of $S V F$-group genes at the expense of correcting the mutation with the shift of reading frame has been described. SVF13 gene is encoded by the transcription factor Mbxlp. But mutation +1 of the reading frame is revealed in this gene. Synthesis of suppressor, providing the skipping of +1 base, takes place simultaneously. As a result the level of transcription, determined by Mbxlp factor, depends on the level of synthe- 

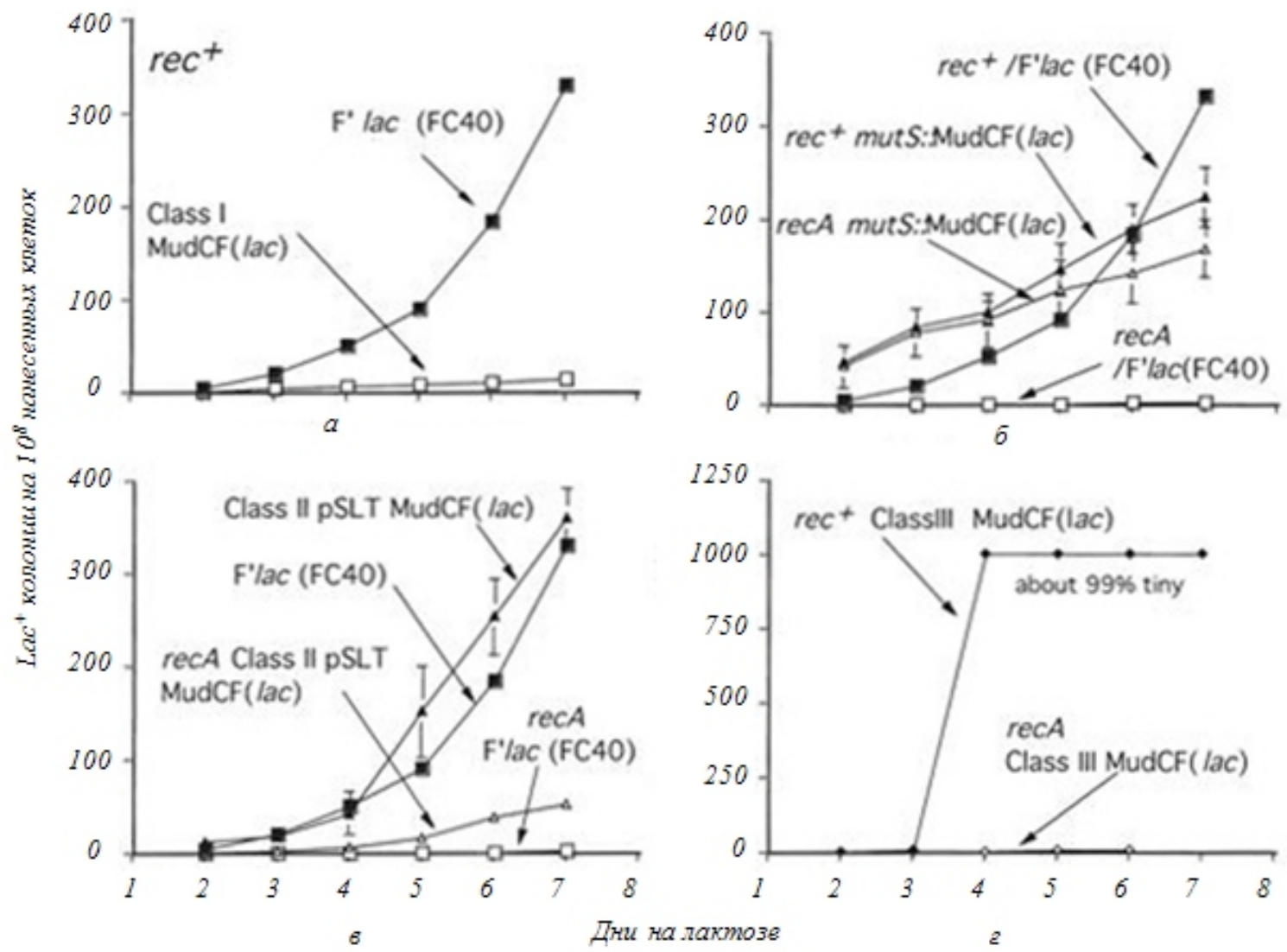

Fig.10 Reversion of lac operon at the insertion of MudCF in several different positions: $a$ - typical insertion of MudCF class I (shaded squares TT18302 (rec ${ }^{+} / F^{\prime}$ lac); empty squares - TT20853 (rec+, oadB10::MudCF)); $b$ - A mutS177::MudCF insertion (shaded squares TT18302 ( $\mathrm{rec}^{+} / \mathrm{F}^{\prime}$ lac); empty squares - TT18306 ( $\mathrm{rec}^{-}$, oadB10::MudCF)); shaded triangles - TT20864 rec ${ }^{+}$, mutS::MudCF)); $c-$ typical in-

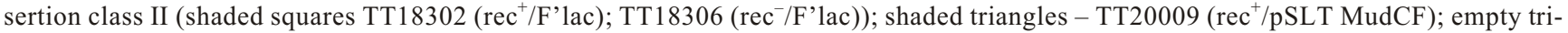
angles - TT23011 (rec-pSLT MudCF)); $d$ - typical insertion class III (empty triangles TT22996 (rec ${ }^{+}$, dbpA::MudCF); shaded triangles TT23014 (rec+, dbpA::MudCF)) [31].

sis of suppressor of mutation with the shift of reading frame [37]. The process of regulation can be complex and complicated. Thus, one of the key regulators of such process in yeasts is the MMR-proteins. The increase in mutations with the shift of reading frame takes place at any kind of switching off their activity (functional or mutational). It takes place on 8 -member hot-spots. Almost $25 \%$ of all genes in these organisms contain 8-member poly-A or poly-T tracks. And these tracks are highly-stable in genome (i.e. are not chipped off). However, there are highly-labile poly-G or poly-C tracks, on which the mutations take place especially actively. The intensities of these processes have been demonstrated on the reverse of $l y s^{-}$into $l y s^{+}$. The frequency of restoring $\mathrm{lys}^{+}$increases 100000 times at the presence of such tracks in $l y s^{-}$gene and the content of inactivating Rsh 2 mutation in genome [38].

Contrary to spot-mutations with the substitution of the bases, the regulatory role of mutations with the shift of reading frame may have rather logical explanation by the fact that the shift occurs preferably (or even solely) on some hot-spots, i.e. on certain sequences (not just anywhere), and due to this it may be performed in the gene spot, specified for this purpose. Overcoming of the shift of the reading frame is conditioned by special proteins, also encoded in genome. Therefore, both 
Table 8

Three types of developed regulatory genomic reorganisations and taxons, where the reorganisations occurred

\begin{tabular}{|c|c|c|}
\hline Category & Type of reorganisation & Taxon \\
\hline 1. & $\begin{array}{l}\text { Wide range of } \\
\text { reorganisations }\end{array}$ & $\begin{array}{l}\text { Animals: Nematodes, } \\
\text { Copepods, Hagfish, } \\
\text { Foraminifera, Ciliates }\end{array}$ \\
\hline \multirow{3}{*}{2.} & \multirow{3}{*}{ Target reorganisation } & $\begin{array}{l}\text { Immune system of } \\
\text { vertebrates }\end{array}$ \\
\hline & & Tripanosomes antigenes \\
\hline & & Type of yeast coupling \\
\hline 3. & rNDA - special case & $\begin{array}{l}\text { Animals, Enthamoeba, } \\
\text { Euglenids, Dictyostelids and } \\
\text { myxomycetes Ciliates }\end{array}$ \\
\hline
\end{tabular}

shifts of the frames and their overcoming, and the possibility of the latter, are controlled processes. The shift of the frame in these processes is just one of the elements of the regulation.

Considering the mutations in soma cells, as elements of regulation, possible objection is the relative rarity of such events. Let it be $10^{-5}$, or even $10^{-3}$, but this is in a single cell per 100000 or per 1000 . And the regulation of all targets by the proteins is $100 \%$. It is true arithmetically. But it is impossible to limit the regulation by arithmetic. Protein regulation, which is both diverse and quantitatively different for some types of cells (including closely located ones), is not the same (Fig.11). Neighbouring cells are functionally not the same! Therefore, the cells of one and the same tissue are heterogeneous in their regulation. But even if we come out of the frequency of mutations only, $10^{-5}-10^{-3}$ is the enormous value for soma. Every human "consists" of $\sim 5 \cdot 10^{13}$ of cells. Strictly quantitative data show that the mutant cell may produce the clone of any size at any probability of its occurrence, which is evidenced by the clone selection of lymphocytes, carrying the antibody, necessary for the organism. And it concerns all tissues and organs. The attention to this phenomenon is paid only when it is hard not "to see" it. E.g. Different types of mutations by different genes in soma result in the occurrence of spots in swine (Fig.12). Every spot is the mutation in one gene of one cell. Then, the multiplication to the size of the spot occurs. The result can not be neglected - the spots are of different colours. These spots were subdued to the detailed analysis. However, the mutations are not limited by the occurrence of the spots. Corresponding mutations will also take place in all the genes, where it is necessary to the organism. And this can be omitted... and it is omitted.

Finally, let us take a look at the methylation. It seems like the works, carried out on monozygotic twins, are the most prominent in this respect. Monozygotic twins are clones both actually and according to the mechanism of origination. As in any clones, their genomes are identical. Identical in everything, including the methylation. However, when the amazing method, allowing the identification of methylation of genome in each separate twin, i.e. distinguishing the differences between them, was elaborated, the result was astonishing. In the young age, the conditions of life of twins were "twin-like" and the pattern of methylation revealed the identity experimentally. But, later on, the conditions of their lives were separated and the methylation of genomes, identical since birth, acquired some significant differences [41]. It may occur only in the case when the methylation is the regulation of fine adjustment of the whole genome. The adjustment to actual life and actual environment. Only a part (and very limited part) of the whole genome is subject to the classical regulation - via signalling pathways and protein regulators. The other part is assumed to work in the constitutive mode. It is true in regards of experimental determination of expression range at different effects in the real time of regular experiment. Constitutively working genes do not change their expression at once, and, in fact, they should not. But general fine re-adjustment can not but take place at long-term changes in living conditions. General and generally-correlated! After that, constitutive genes will work again in the narrow range of changes in the levels of their expression (organism is way too complicated to change everything, everywhere, and at once in respect of each, usually transient, change in some external factor). As for new stationary level of living, re-adjustment is necessary.

"Mutational crisis" i.e. understanding of the fact that the assumptions of mutations require serious reviewing, leads to the problem of reconsidering basic biological concepts. Investigations of certain processes and events prevent us from seeing the life as phenome- 
non! Meanwhile, life is a unique phenomenon. It is based (based, exactly so) on absolutely outrageous destructive processes. The latter are so inexpressibly powerful and rapid, that no non-living matter would survive them. Whereas they are foundations of life, necessary for the existence: breathing (all types of oxygen transformation), peroxides and radicals, high-energy intermediary products of enzymatic chains, energy transfer between macromolecules and inside them, enzymatic (i.e. high-catalysis) reactions, functionally directed towards the destruction, degradation of everything, including cell material of its own (proteases, nucleases, lipases etc) and it goes like that everywhere. From the standpoint of the occurring events, life is a continuous self-directed metabolic informational explosion. These processes proper supply the energy, sufficient for living, for all constructive metabolism and all forms of protection from anything, present on the Earth (and reaching the Earth from the Space). In order for all this constantly and permanently working, explosion-like destructive stuff not to tear the cell apart into tiny molecular pieces, it is organised properly in space and time, with strict subordination to the most effective control. In its structural and functional organisation the simplest organised cell is the dream of all nanotechnologies, absolutely impossible in the nearest future. Mutations are to be viewed in the context of all these processes and not as just occasions. The first stage on the way to such new concepts on mutations is the evaluation of role, contribution, meaning, etc of mutations in various life continua, where mutations are similar in their role, contribution, meaning, etc (some "continua of mutational similarity"). Continuum of mutational similarity of germ plasma (germ route, germ line) and continuum of mutational similarity of vertebrata soma are the first in the context of the aforementioned materials (i.e. the most studied ones, and the most current for us).

Germ route is the classics of concepts on mutations. All existing concepts on the laws of inheritance, namely mendelian inheritance, recessives and dominants, penetrance and expressivity etc, were created on the basis of mutations on germ route (through the realisation in soma, but in all of its cells as derivatives of germ route). Later on, all this was extrapolated, transferred, generalised etc onto soma in its pure form

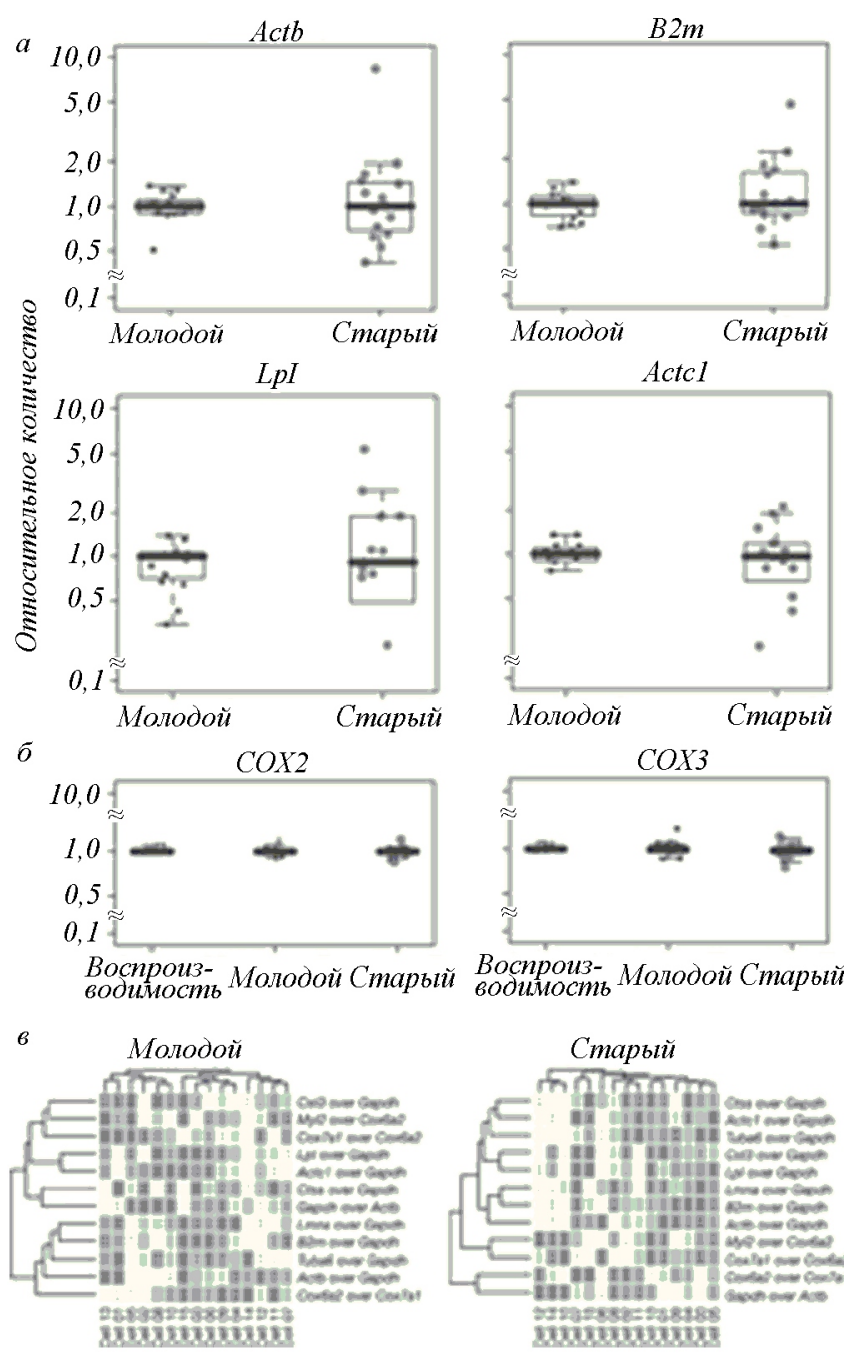

Fig. 11 Increased variability from cell to cell of gene expression in cardiomyocytes of old mice compared to hose of the young mice: $a$ - examples, revealing statistically trustworthy differences from cell to cell in the expression of four genes (Actb, B2m, Lpl, and Actcl, standardised by Gapdh) $b$ - expression of mitochondrial genes of cytochrome c oxidase (standardised by COX1) in the same cells did not reveal statistically significant increase at random selection (10 repaets for old and young cells from one etalon were analysed for determining RT-PCR error); $c$ - representative cards of one young and one old mouse revealed significant differences in cell samples (estimated for each gene), which testifies on randomness of the differences observed from cell to cell [39].

according to ready made, well-established and commonly accepted provisions (perfectly proven in practice), well studied and justified in generative lines only, depending on the appearance of methodological possibilities of soma analysis. The situation of such abso- 

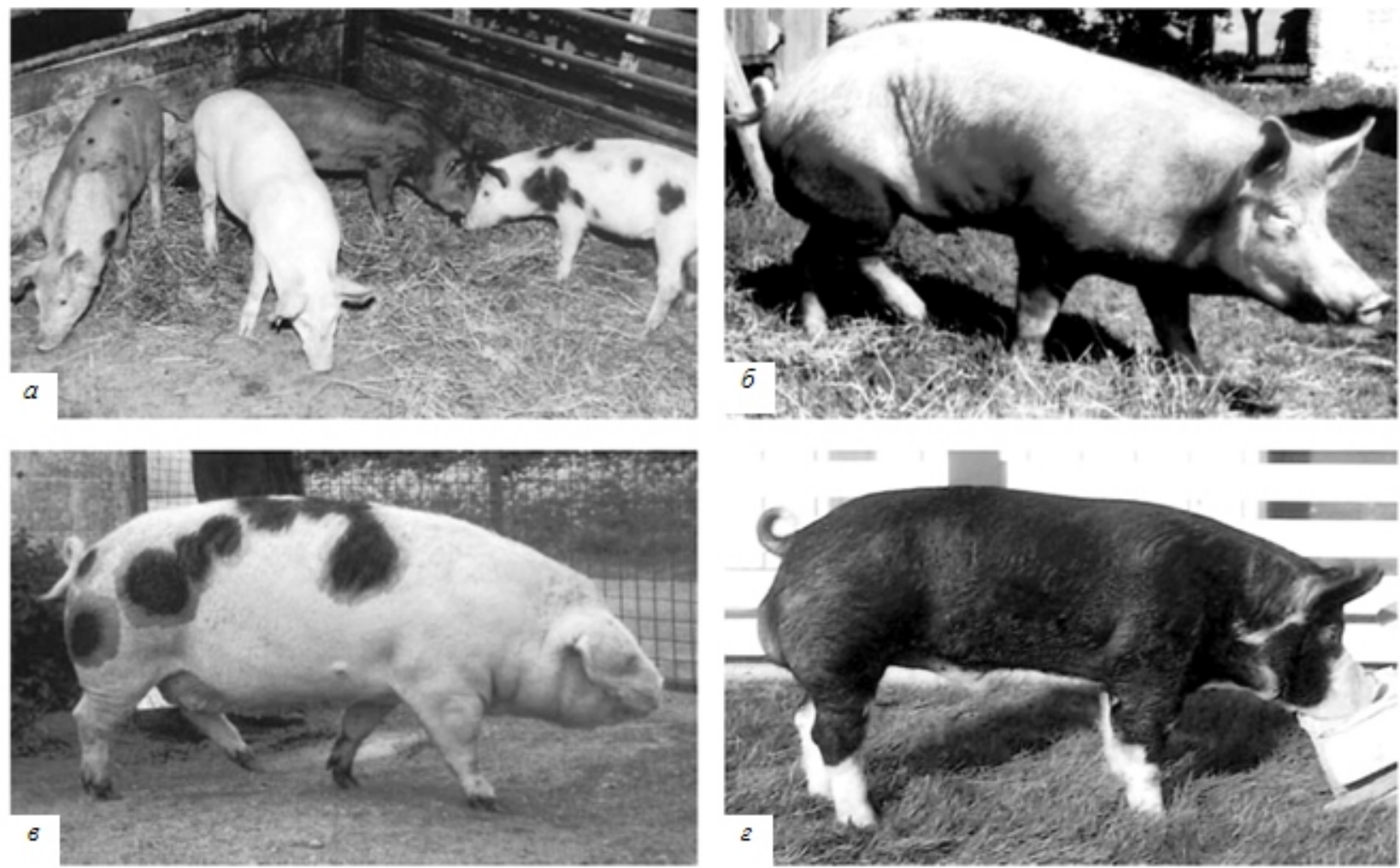

Fig. 12 Demonstration of different types of colour phenotypes, connected with allele of $\mathrm{E}^{\mathrm{p}}$ locus Extension/MC1R: $a-\mathrm{F}_{2}$ generation - hybrid of wild sore and big white soar (pigs (left to right): $1-\left(\mathrm{E}^{\mathrm{p}} / \mathrm{E}^{\mathrm{p}}\right)$, red colour with black spots, phenotypically close to Lingirod swine (not presented); 2 - white spots, occur due to the presence of white allele; 3 - heterozygote $\left(\mathrm{E}^{+} / \mathrm{E}^{\mathrm{p}}\right)$, has got white type colouring on bottom right side, which shows somatic reverse; $4-\left(\mathrm{E}^{\mathrm{p}} / \mathrm{E}^{\mathrm{p}}\right)$, white with black spots, colouring is similar to Pietrain (not presented)); $b-\mathrm{Tamworth} ; c-$ Gloucester Old Spot; $d$ - Berkshire (photo A. Christian and M. Rothschild, Lowa State University) [40]

lutely inadequate transfer was complicated by the fact that, though mutations occurred and secured in the germ route, they were realised in soma! Even so the generalisation seemed so obvious that there was no room for doubt left. Reality made its way through with enormous efforts - mutation in the germ route results in subsequent obligatory reproduction, multiplication in all cells, descendants of such initial mutated cell of germ route. If the mutation of the germ cell initiated the soma, it will provide "its" mutation in all soma cells. All of them! And germ route genotype (!!) is realised in soma phenotype (!!!). Everything is predestined by it mutation takes place in the germ route, but later on, once it is secured, it is to be transferred in "its" germ route and realised in soma. Transferred in the germ route and realised in soma. At the same time, functional task of the germ route is the maximal (theoretically ap- proaching the absolute) informational conservatism. Function-wise, there should be no mutations in the germ plasma whatsoever. Otherwise, the latter does not fulfil its functions and is to be eliminated as a line. It occurs due to inconsistency of soma, which occurred from such germ route, carrying it, to the external conditions. Due to inconsistency of the germ route to soma, which it contains, i.e. to the internal conditions. Inconsistency of competitiveness of "revealing agent" of its functional applicability in regards to other germ routes in other soma etc. Therefore, everything in the germ route is directed towards the elimination of mutations by any means - both "internal" (using systems of protection, reparation, maximal decrease of biochemical activity while having the maximum of everything required from surrounding soma cells, etc) and "external" (by elimination inside, in generative sphere of cells - 
mutation carriers). For this purpose, in some currently unknown way, mutations are absolutized in cascades into disorders of germ route cells, which are incompatible with further existence (fulfilling functions) of those germ route cells, which have the mutations (initial, resulting in chain accelerative reaction). This is the only way to explain inconceivable reality. The final stage of each single functional cycle of germ plasma is resulted in the way from mature germ cells through the entire subsequent embryogenesis back to mature germ cells. Every end of this way is characterised by both enormous absolute value and percentage of mature germ cells with large chromosomal disorders, incompatible with vitality and/or fulfilment of functions. Thus, in case of human oocytes, the data of different laboratories regarding chromosomal abnormalities in healthy women in different populations were shown to fluctuate from 4.5 to $47.7 \%$ (Table 2), and the average value determined by the karyotypes of 1120 oocytes was $35 \%$ [42]. In case of spermatozoids these values amounted from one to several dozens percent in the most favourable selections [43-45]. These values grew intensively in unfavourable populations reaching $100 \%$. This situation is the massive elimination of something which is the criterion for the germ route, and is continuously observed at all of the germ route stages. The number of germ cells in female germ route in 7 -month-old fetus increases to $(6-7) \cdot 10^{6}$ as a result of multiplication. Then the elimination takes place and not more than 400 remains till ovulation, i.e. app. 99.994\% is eliminated [46, 47]. Elimination is even higher in male germ route taking into account post-natal processes. There it is - if we assess the number of mutations according to commonly accepted methods, it is higher in germ route cells than in soma, and their elimination is so high that if it were the same for soma, there would be nothing left of soma whatsoever (several thousandths per cent would be sufficient for one exfoliated furfur). However, due to such uncompromising character, the life on the Earth has been going on for 4 billion years, and the species (in its rather stable condition) exists on average for several millions years.

Soma has whole way different tasks (and everything, including mutations, is submitted to these differences). Contrary to the germ plasma, whose line is potentially endless, the line of soma is always the dead end, represented by an organism, specimen, individual, i.e. terminal something, potentially limited by species lifetime, functional task of which is the preservation and the transfer of the germ route only (only!). This is the "nature"-predetermined way. And no matter who, how, and how much would disagree with it, it means nothing for life as phenomenon. Somebody disagrees, so what? Does this somebody live longer after that? No, he does not. Has he not performed his function, prescribed to him by life as phenomenon? Then germ plasma line will eliminate him, definitely and exclusively him (which is also foreseen by life), along with him and in him. Only now the work starts on turning "disagreements" into something tangible. One of the elements of such "turning into" is understanding of the specificities, differences, mechanisms of everything, which takes place in soma and the germ route. Mutations comprise one of the elements of such understanding.

Mutations in soma are radically, conceptually, principally etc different from what is specific for germ route, both according to the tasks of soma and in its origin, realisation, functions. In the case of soma these are different variants of regulation (of everything!!), including informational variety. Recombination and reading frame shift are the genius solutions of life as phenomenon. In its potential possibilities, this is almost endless increase in soma informational bulk with no change in germ plasma informational bulk. As of date there are no literature data. Still the attention has been paid to a nematode, having a larger gene number-wise genome than an insect (Drosophila). As for human it is only $2-3$ times larger than in a fly. How is that possible? One of the variants is the occurrence of new genes in soma. In the case of germ plasma, the less number of genes is, the better (easier to preserve their stability). Almost all of its genes, except of household genes, are quiet. Soma is supposed to react to everything external and internal. The possibility of increasing the informational bulk is encoded in genome. This means that not the whole information is encoded, but rather the possibility of its increase and creation of new one.

Besides potential possibilities of recombinations and mutations with the shift of reading frame, all alternative variants of gene expression (including alterna- 
tive splicing, transcriptional frame shift and editing) may result into genes via reverse transcription (function of RNA-dependent DNA-polymerase). They result in separate (and different) cells of different tissues and organs. On completion of the required functions, the cells with such new genes are eliminated in loads as it takes place in embryogenesis. Elimination of cells in soma is the continuous and massive process. There are more than enough possibilities for the reverse synthesis in soma. Only $L 1$-elements, encoding the protein with the sequence, which is consensus-like to known reverse-transcriptases, are abundant in all mammals [48, 49], their number in human is close to the number of his structural genes [50]. Actually (in case of the presence of necessary sequences) homing-endonucleases may assist the same (i.e. transfer not only introns) [51]. Indirect evidence to the fact that genes formed anew occur in fact, is the blocking of embryonic development through the introduction of antibodies, inactivating revertase [52]. Fine adjustment of the whole genome via its methylation "pursuant to requirement" provides something which can not be encoded as a ready made product in genome "for all life occasions" by any means. Something like this can either not be present in the germ route (the formation of new genes due to recombination, re-synthesis or reading frame shift, diminution, regulatory mutations), or it has completely different functional load (magnification, purifying chain mutational reaction, switching the development programmes by methylation). According to classical ideas, mutations are determined by their securing in germ route (and generally called "genotype") via the realisation in soma (already mentioned "phenotype"). Later on it goes to common way. It is either hereditary diseases (if we are talking about humans) or "evolutionary meaning". And whatever is defined as changes in genome of somatic cells (which are not transmitted via sexual reproduction) is epigenetics. Whatever, the main thing is not to step aside from canons.

There is a need to change the mutational paradigm. Change it de novo, to review what the mutation is, taking into account the whole bulk of data and knowledge. Hugo De Vries was an outstanding naturalist. However, it has been more than 100 years since his introduction of the notion of mutation. In the last 100 years science in general and biology in particular accumulated enormous amounts of experimental data, created new methods and technologies, developed concepts and theories and so forth and so on, many times more, than throughout previous history of the mankind.

And as for nowadays, it is possible to speak about mutations, although they are considered to be the consequences of natural processes (as well as other things in the living), yet they are designed by life to perform necessary tasks and to bear functional loads. The kinds of tasks vary on the groups of the living. Moreover, they are to be viewed not generally but substantially. And not like the "stochastic occasion" as everything in the living is highly organized.

Three lines can be distinguished in vertebrates (one of the most studied mutational continua), three continua of mutational community, i.e. 1) mutations and mutagenesis in the germ plasma; 2) mutations and mutagenesis in soma; 3) mutations and mutagenesis in artificial, unnatural systems (cell cultures, cell lines, cell populations, etc).

Each of them should have its own ideas, theories, methods of the research, and technology of application. Modern "classics" does look weird, doesn't it? For instance, the culture of immortalized cells is dropped upon by different substances, and according to the occurring mutations "protective effect" or "mutational spectrum" of different preparation for the human being is determined. In the cell cultures the reactions and the behavior of cells is one, in soma (where the perspective preparation will be introduced to) the function of mutations is different (and their "inhibition" in organs and tissues may result in anything), whereas in the germ line everything is quite opposite at all (if there would be any obstacles on the way of chain mutational purifying processes, it may produce the opposite effect, i.e. some classes of mutations will be enriched, but they do not result in lethal ends or bright phenotypical manifestations, which will not be observed by the experimenter immediately). And it includes everything.

Let us make some absolutely non-canonical resume. Mutations are covalent changes in genome, supplementing traditional regulation (based on protein-nucleic interactions) - highly labial one with more conservative one. Ex facte five levels of regulation by covalent changes in genome (mutations) can be distinguished as follows: 1) damage of bases; 2) methylation 
of bases; 3) point mutations (of all types); 4) reorganisation of genome; 5) formation of new genes. Common views on mutations are based on the events, taking place in the germ route, via realization in soma. But in both soma and the germ route the ways of regulation and realization are quite different. And therefore, the notion of "mutation", applied to them can not be similar. All cell cultures outside of the organism live their own special extraorganismal life, nothing similar with the natural one (and it has not been analysed at all, what it really is).

Mutations in several generations in germ plasma are the subject of genetics (the science on heredity and inheritance). Whereas mutations in soma are subject to regulations. The attempts to bring it down to heredity and inheritance, i.e. to genetics, having added epi- prefix is nothing but tribute to tradition. Of course there is epigenetics - inheritance is thus combined, contacted, and interacted etc. with it. Yet to limit the regulation (even if it is not common to us and is determined by covalent changes of genome in soma) to genetics (in its modern, but yet traditional understanding) is impossible, i.e. possible no more.

For germ plasma (continuous, "individual-through" line of life), mutation, influencing something is not only the change in gene. It is also potential danger for the weak, which changes not the functions of changes "almost" at the level of mononucleotide polymorphism of mutations. Some signal, indicating that the system of reparation in this exact cell of the germ line did not cope with, missed it (while in other cases, coped with, there are no mutations, yet the level of damageability is the same everywhere statistic-wise). If it did not cope with that it is possibly dangerous as it may not cope with other mutations. And this cell has got to be eliminated (in accordance to the functions of germ line) from the germ line. The cascade of changes, resulting in subsequent large, incompatible with further existence, chromosomal disorders. Reparation in its regulation and realisation is very large-scale. One third of all genes is involved in reparation even in bacteria, and almost all of them are involved in cytogenesis. Therefore, there is something to be included for checking. And thus, normal human germ cells (!) from one to tens percent of gametes are aneuploid. These are the authorised cleaning mutations, initiating the cleaning cascade. Whereas those that for some reason did not cause the latter and went through into the reproduction are the unauthorised mutations. They are the source of polymorphism, hereditary diseases included.

Mutations perform regulatory functions in genome, directed towards the provision of soma existence. These are the authorised mutations. Being out of control, mutations in soma cause pathology, i.e. oncogenesis. These are unauthorised mutations. In germ route mutations perform "cleaning" functions, directed towards providing consistency of germ plasma in the continuous line of life. Once uncontrolled, mutations in germ plasma result in pathological inferiority, incompatible with continuous existence of life, i.e. hereditary diseases.

Mutations in soma and the germ route are different in their origin, contents, tasks, significance, functions, and consequences. Common thing for all of them is the fact that mutations are as necessary attribute of life as breathing, energetic metabolism, biosynthesis. Therefore, it is conceptually hopeless to fight mutations "in general". Mutations are to be directed, as everything else in the living. Not to fight them but to control them. We can not stand the fact that we are the terminal state in the form of self-controlled community of cell populations, carrying, protecting, and feeding, etc continuous line of germ plasma. But we will have to, of course, if we want to understand how to step out of the terminal.

\section{B. А. Кордюм}

Мутации - это что?

Резюме

Анализируются представления о мутациях. Приведены литературные данные, не соответствующие существующим концепциям о мутациях. Сформулировано положение о функииональной неоднозначности мутаций $u$ их биологическом значении. Согласно этому положению, мутации в соме выполняют регуляторные функции, являясь, таким образом, нормальной, контролируемой организмом, составляющей биологических прочессов. А выходя из-под контроля, мутации в соме приводят к онкогенезу. В зародышевом же пути мутации через каскадные интегральные проиессы обеспечивают элиминацию их 
носителей, выполняя очистительную функцию. А при выходе из-под контроля, не приводя к элиминации их носителей, реализуются в наследственную патологию во всем ее диапазоне - от скрытой формы («мутационный груз») до яркой манифестаиии.

Ключевые слова: мутачии, регуляция, сома, зародышевый nymb.

\section{REFERENCES}

1. Гершензон С. М. Основы современной генетики.-Киев: Наук. думка, 1979.- 508 с.

2. Mohrenweiser H. W., Jones I. M. Review at the molecular characteristics at gene mutations at the germline and somatic cells at the human // Mutat. Res.-1990.-P. 87-108.

3. Drake J. W. Mutation: major evolutionary trends $/ / 18^{\text {th }}$ Symp. Nucl. Acids Chem. (Sendai, Oct. 29-31, 1991).-Oxford etc., 1991.- P. 159-160.

4.Ono T., Lehara Y., Saito Y., Ikehata H. Mutation theory of aging, assessed in transgenic mice and knock-out mice // Mech. Ageing and Develop.-2002.-123.-P. 1543-1552.

5. Слозина Н. М., Неронова Е. Г. Хромосомные аномалии гамет человека и внутриутробный отбор. Исследования женских гамет // Цитология и генетика.-1992.-26, № 6.-C. 58-63.

6. Morley A. A., Turner D. R. The contribution at exogenous and endogenous mutagens to in vivo mutations // Mutat. Res.-1998.-428.-P. 11-15.

7. Shastry B. S. SNP alleles in human disease and evolution // J. Hum. Genet.-2002.-47.-P. 561-566.

8. The International SNP Map Working Group. A map at human genome sequence variation containing 1.42 million single nucleotide polymorphisms // Nature.-2001.-40.-P. 928-933.

9. Rosen E. M., Fan S., Pestell R. G., Goldberg I. D. BRCA1 gen in breast cancer // J. Cell. Physiol.-2003.-196.-P. 19-41.

10. Hasin Y., Avidan N., Bercovich D., Korczyn A., Silman I., Beckmann J. S., Sussman J. J. A paradigm for single nucleotide polymorphism analysis: The case of the acetylcholinesterase gene // Hum. Mutat.-2004.-24.P. 408-416.

11. Pagani F., Raponi M., Baralle F. B. Synonymous mutations in CFTR exon 12 affect splicing and are not natural in evolution // Proc. Nat. Acad. Sci. USA.-2005.-102.P. 6368-6372.

12. Хатынова М. А., Буфф Е. М., Могила В. А., Набирочкин С. Д., Симонова О. Б., Герасимова Т. И. Индукция мутагенеза в результате некоторых генетических скрещиваний // Генетика.-1992.-28, № 3.-С. 56-67.

13. Eriso S., Choi S.-W., Girelli D., Mason I., Dolnikowski G. G., Bagley P. J., Olivieri O., Jacques P. F., Rosenberg I. H., Carrocher R., Selhub J. A common mutation in the 5, 10-methylenetetrahydrofolate reductase gene affects genomic DNA methylation through an interaction with folate status // Proc. Nat. Acad. Sci. USA.- 2002.-99.P. 5606-5611.

14. Садлер Т. В. Медична ембріологія за Лангманом.-Львів: Наутілус, 2002.-550 с.

15. Мишин В. П., Богнарев В. В., Чурюканов В. В. Кислород // Большая мед. Энциклопедия.-М.: Сов. Энциклопедия, 1979.- T. 10.- C. 325-326.
16. Fraga C. G., Shigenaga M. K., ParkJ.-W., Degan P., Ames B. $N$. Oxidative damage to DNA during aging: 8-Hydroxy-2'-deoxy- guanosine in rat organ DNA and urine // Proc. Nat. Acad. Sci. USA. - 1990.-87.-P. 4533-4537.

17. Кордюм B. A.. Наша «шагреневая кожа» - это наша проблема. Нам ее и решать.-Киев: Логос, 2006.-245 c.

18. Hamilton M. S., Remmen H. V., Drake J. A., Kang H., Guo Z.M., Kewitt K., WalFrter C. A., Richardson A. Does oxidative damage to DNA increase with age? // Proc. Nat. Acad. Sci. USA -2001.-98.- P. 10469-10474.

19. Richter Ch., Park J.-W., Ames B. N. Normal oxidative damage to mitochondrial and nuclear DNA is extensive // Proc. Nat. Acad. Sci. USA.-1988.-85.-P. 6465-6467.

20. Loeb L. A., Cheng K. C. Errors in DNA synthesis: A source of spontaneous mutations // Mutat. Res. Rev. Genet. Toxicol.-1990.- P. 297-304.

21.Frosina $G$. Overexpression of enzymes that repair endogenous damage to DNA // Eur. J. Biochem.-2000.-267.-P. 2135-2149.

22. Lu T., Pan Y., Kao S.-Y., Li C., Kohane I., Chan J., Yankner B. $A$. Gene regulation and DNA damage in the ageing human brain // Nature.-2004.-429.-P. 883-891.

23. Dolle M. E., Snyder W. K., Dunson D. B., Vijg J. Mutational fingerprints of aging // Nucl. Acids Res.-2002.-30P. 545-549.

24. Vijg J., Dolle M. E. T. Large genome rearrgements as a primary cause at aging // Mech. Caging and Develop.-2002.-213.- P. 907-915.

25. Khil P. P., Camerino-Otero R. D. Over 1000 genes are involved in the DNA damage response of Escherichia coli // Mol. Microbiol.-44.- P. 89-105.

26. Jahn C. L., Klobutcher L. A. Genome remodeling in ciliated protozoa.-Palo Alto, 2002.-520 p.

27. Yan B., Wang H., Peng Y., Hu Y., Zhang X., Chen Q., Bedtard J. S., Dewhirst M. W., Li C.-Y. A unique role at the DNA fragmentation factor in maintaining genomic stability // Proc. Nat. Acad. Sci. USA.-2006.-103.- P. 1504-1509.

28. Невзорова T. А., Винтер В. Г. Исследование ДНК-гидролизующей активности антител к ДНК // Уч. зап. Казан. гос. ун-та.-2005.-Т. 147, ч. 2.-С. 136-148.

29. Cairns J., Overbough J., Miller S. The origin of mutants // Nature.-1988.-335.-P. 142-145.

30. Cairns J., Foster P. L. Adaptive reversion of a frameshift mutation in Escherichia coli // Genetics.-1991.-128.P. 695-701.

31. Slechta E. S., Harold J., Andersson D. I., Roth J. R. The effect at genomic position on reversion at a lac frameshift mutation (lac LZ33) during non-lethal selection (adaptive mutation) // Mol. Microbiol.-2002.-44.-P. 1017-1032.

32. Metzgar D., Bytot J., Wills C. Selection against frameshift mutations limits microsatellite expansion in coding DNA // Genome Res.-2000.-10.-P. 72-80.

33. Zufall R. A., Robinson T., Katz L. A. Evolution of developmentally regulated genome rearrangements in eukaryotes // J. Exp. Zool. B.-2005.-304.-P. 448-455.

34. Zhang $Q$., Wise K. S. Localized reversible frameshift mutation in an adhesion gene confers a phase-variable adherence phenotype in mycoplasma // Mol. Microbiol.-1997.-25.-P. 859-869.

35. Theiss $P$., Wise K. S. Localized frameshift mutation generates selective, high-frequensy phase variation at a surface lipoprotein encoded by a mycoplasma $\mathrm{ABC}$ transporter operon // J. Bacteriol.-1997.-179.- P. 4013-4022. 
36. Matsui K., Yamada M., Imai M., Yamamoto K., Nohmi T. Specificity of replicative and SOS-inducible DNA polymerases in frameshift mutagenesis: Mutability at Salmonella typhymurium strains overexpressing SOS-incducible DNA polymerases to 30 chemical mutagens // DNA Repair.-2006.-5.-P. 465-478.

37. Hendrick J. L., Wilson P. J., Edelman I. I., Sandbaken M.G., Ursic D., Culbertson M. R. Yeast frameshift suppressor mutations is the genes coding for transcription factor $\mathrm{MbH} 1 \mathrm{p}$ and ribosomal protein S3: Evidence for autoregulation at S3 synthesis // Genetics.-2001.-157.- P. 1141-1158.

38. Harfe B. D., Jinks-Robertson S. Sequence composition and context effects on the generation and repair at frameshieft intermediates in mononucleotide runs in Saccharomyces cerevisine // Genetics.-2000.-156.- P. 571-578.

39. Bahar R., Hartmann C. H., Rodriguez K.A., Denny A., Busuttil B.A., Dolle M. E. T.,Calder R. M., Chisholm G. B., Pollack B. H., Klein C. A., Vijg J. Increased cell-to-cell variation in gene expression in ageing mouse heart // Nature.-2006.-441.-P. 1011-1014.

40. Kijas J., M. H., Moller M., Plastow G., Andersson L. A Frameshift mutation in MC1R and a high frequency at somatic reversions cause black spotting in pigs // Genetics.-2001.-158.-P. 779-785.

41. Froga M. F., Ballestar E., Paz M. F. Epigenetic differences arise during the lifetime at monozygotic twins // Proc. Nat. Acad. Sci. USA.-2005.-102.- P. 10604-10609.

42. Zenzes M. T., Casper R. F. Cytogenetics of human oocytes, zygotes, and embryos after in vitro fertilization // Hum. Genet.-1992.-88.- P. 367-375.

43. Tempiado C., Benet J., Genesca A., Navarro J., Cabalin M. R., Miro R., Egozcue J. Human sperm chromosomes // Yum. Re- prod.-1988.-3.-P. 133-138.

44. Pellestor F., Jel B. Йtude cytogŭnйtique du sperme humain // M/S: Med. Sci.-1989.-5.-P. 244-251.
45. Benkhalifa M., Malet P. Menezo Y., Janny L., Boucher D. Cytogenetic analysis of human gametes to embryos: Abstr. 6 Int. Conf. Early Prenat. Diagn. Genet. Diseases from Gametes to Embryo // Prenat. Diagn.-1992.-12, Suppl.-P. 50.

46. Теппермен Дж., Теппермен X. Физиология обмена веществ и эндокринной системы.-М.: Мир, 1989.-656 с.

47. Фільченков О. О., Стойка Р. С. Апонтоз і рак. Від теорії до практики.-Тернопіль: Укрмедкнига, 2005.-524 с.

48. Swergold G. D. Indentification characterization, and cell specificity of a human LINE-1 promoter // Mol. and Cell. Biol.-1990.-10.- P. 6718-6729.

49. Mathias S. L., Scott A. F., Kazazian (Jr.) H. H., Boeke I. J. D., Gabriel A. Reverse transcriptase encoded by a human transposable element // Sci. Mag.-1991.-254.P. $1808-1810$.

50. Woods-Samuels P., Wong C., Mathias S. L., Scott A. F., Kazazian H. H., Antonarakis S. E. Characterization of a nondeleterious L1 insertion in an intron of the human factor VIII gene and further evidence of open reading frames in functional L1 elements // Genomics.-1989.-4.-P. 290-296.

51. Haugen P., Bhattacharya D. The spread of LAGLIDADG homing endonuclease genes in rDNA // Nucl. Acids Res.-2004.-32.- P. 2049-2059.

52. Pittoggi C., Sciamanna I., Mattei E., Beraldi R., Lobascio A. M., Mai A., Quaglia M. G., Lorenzini R., Spadafora C. Role of endogenous reverse transcriptase in murine early embryo development // Mol. Reprod. and Develop.-2003.-66.P. 225-236.
УДК $577.21+575.857$

Надійшла до редакції 18.04.07 